\title{
THE DEVELOPMENT OF REGULATORY SMALL LOAN LAWS
}

\author{
F. B. Hubachex*
}

This symposium is devoted to studying the loan shark and what to do about him. - A loan shark is one who lends comparatively small sums of money as a business, at high and almost always illegal rates of charge under conditions which defraud and oppress the borrower. The antithesis of the loan shark is one who supplies credit in small amounts, at reasonable and legal rates of charge under conditions of fair dealing. Socially, the legitimate lender is the positive pole and the loan shark the negative one. What promotes one destroys the other. They are complements. This article is devoted to studying the legitimate lender. Neither he nor the loan shark can be intelligently considered or dealt with without taking the other into account. Economic forces are at work behind both which determine developments for each. As these forces move, they change the complexion of the many businesses within the consumer credit field, including the business of lending small amounts of cash. The resulting demands for credit find sources of supply-legal or illegal, social or anti-social. This has happened in the past and it is happening today. The public problems constantly presented are always in a state of flux. To the extent that the trends are discerned, accurately appraised, and vigorous action taken, it is possible to safeguard the public and to mold developments by legislation.

Legislation regulating the small loan business has followed developments in that business, belatedly but with' marked persistence. The recurring sequence of social evil and corrective law presents an interesting record of the working of American jurisprudence. An underlying economic change takes place. Among its complex results a maladjustment appears at a different point. The evil is recognized but not the cause. Ancient prejudices or misconceptions come into play. The first effort to correct is a "Thou shalt not." More dislocations follow but public opinion perversely assigns yet other false causes. The partial successes sometimes seem worse than the evil. Finally, thoughtful analysis starts. The causes are recognized by a few. Grad. ually the realities dawn on the mass mind which controls legislation. During this process there is suffering and delay but a solution eventually appears. What is most

- A.B., 1915, University of Minnesota; Harvard Law School, 1915-1917; LL.B., 1922, University of Minnesota. Member of Illinois and Minnesota bars. General Counsel, Household Finance Corporation. Chairman, Law Committec, National Association of Personal Finance Companics. Author, Annotatjons on Small Loan Laws (Russell Sage Foundation, 1938).

The author wishes to acknowledge the collaboration of Mr. Roger S. Barrett of the Illinois Bar in the preparation of this article. 
important, and least likely to be faced with understanding or decisive action, is the fact that this process is a continuous one. The situation never becomes static. At no one time has the correction caught up with the fault. Before the original evil has been properly dealt with the impelling force which created it has swerved in one direction or another. The corrective measure itself sets up forces that produce other dislocations which require new adjustments.

Many of these developments do not come into focus until long after the event. Sufficient time has now elapsed to view the early history of small loan laws in. perspective and to see this process working out. One wonders how the present economic and social conditions of consumer credit will appear in 1960.

Of immediate practical importance is the question how best to formulate legislative policies to deal with evils which are manifest today. The problem is mainly one of recognizing present conditions and tracing down their causes. In this a knowledge of the past.development of small loan legislation will be helpful. In many respects it has been a typical case. Many lessons are there to be learned. Since rgr6 a creditable job of matching laws to evils has been done. Today the small loan business is the only regulated segment of the much larger field of consumer credit. This credit field is subject to grave ills for which legislative cures are being proposed from all sides. It will be a pity if those interested do not study the history of small loan laws and apply the principles which can be deduced from this history to the legislative problems of the larger subject.

This article will review in brief the history of small loan legislation leading to the formulation of the Uniform Small Loan Law in I916, describe the essentials of that model act, trace its principal changes through to its present form, attempt to analyze its effects upon licensee and loan shark, present certain compilations of data with respect to current small loan laws, and mention some of the legislative problems now pressing for consideration.

The evils which exist in the absence of effective small loan legislation are portrayed by other articles in this symposium. In brief, borrowers of small sums lack the equality of bargaining power necessary to fair dealing. Interest rates fixed by general usury laws are too low to permit legitimate lenders to make small loans profitably. Because their contracts are illegal, unscrupulous persons who supply the demand for such loans resort to fraud, chicanery, and oppression to make and collect them.

Small loan legislation undertakes to minimize these evils by (I) authorizing rates of charge sufficient to permit profitable operation by legitimate capital, (2) requiring those who charge such rates to submit to restraints for the borrower's protection, and (3) eliminating lenders who will not conform to regulation. The accepted formula for accomplishing these objectives is the latest draft of Uniform Small Loan Law recommended by the Department of Consumer Credit Studies of the Russell Sage Foundation. ${ }^{1}$ It is the outgrowth of more than fifty years of effort.

1 The First Draft was recommended in 1916 . Since then improved drafts have been recommended in 1918, 1919, 1923, 1932, and 1935. The various drafts have reflected the accumulation of experience. Each draft has involved additional regulatory provisions to protect borrowers. The Uniform Small Loan 
Much has been written already concerning the early history of small loan legislation. The close student of this subject will find in the literature ${ }^{2}$ a thorough treatment of the early developments. That ground will not be covered de novo in this article, but there will be given a brief résumé of the events leading to the period of modern small loan legislation, with which we are primarily concerned. Distinguished authors divide this early history into three periods: Early, Experimental, and Coor. dinating.

\section{EARLY ATtEMPts ${ }^{3}$}

Very early there had been some groping efforts by state legislatures to deal with the problem of usury in small loans, but there was no marked legislative activity in this field until the closing twenty years of the nineteenth century, during which the existence of a small loan problem was gradually perceived by legislatures. The small loan was then considered a social evil or a problem of poverty rather than an economic factor or necessity. While a few laws were passed designed to encourage semi-philanthropic lending, legislation was mainly directed toward reenforcing general usury laws, enacting them in new states, or prohibiting various practices which were only fragments of the real problem. This merely reflected the policy of condemnation without analysis. Rarely did such legislation take account of the inherent necessity to permit rates of charge commensurate with the costs of making small loans. This failure in turn arose from lack of appreciation of the fundamental changes which were taking place in the national economy. As more families became dependent on wages alone, interruptions in their steady flow or emergency needs for money made a source of small loans a more pronounced necessity. But the demand was mistaken for improvidence or perversity and the cry was "stop the lending."

Prohibitive legislation continued to be ineffective or worse. The demand for small loans expanded progressively and was filled by illegal lenders. The legislation of the time was easily avoided because it failed to cover the entire field. Some laws, for instance, applied only to loans secured by wage assignments and others to loans secured by chattel mortgages. The illegal lender simply framed his transactions to place them outside the scope of the law. The most fundamental deficiency in all

Law as such is merely a model, but most small loan legislation enacted since 1916 has in general followed the draft current at the time of its enactment.

${ }^{2}$ Gallert, Hilborn and May, SMall Loan Legislation (Russell Sage Foundation, 1932). Sec particularly the following chapters: Basis of, c. I, II-17; Early Attempts, c. IT, I8-26; Experimental Period, c. III, 27-52; Coordinating Period, c. IV, 53-88; Era of Uniform Small Loan Law, c. VI, 99-1 12.

Robinson and Nugent, Regulation of SMall Loan Business (Russell Sage Foundation, 1935). Sce particularly the following: Historical Background of Lending, c. I, 13-28; Basis for Existence of Small Loan Business, subsection of c. III, 70-72; Causes of Anti-Social Lending Conditions, subsection of c. III, 72-73; Early Remedial Efforts, c. IV, 74-94; Development of the Uniform Small Loan Law, c. V, 96-113.

${ }^{3}$ In Gallert, Hilborn and MAY, op. cit. supra note 2, c. 11 , 18-26, this period is described as 1884-I898. The writer, believing that the development was gradual and finding no important event to signalize the opening or-closing of each period, has blended them into each other. 
this legislation, however, was that it depended for enforcement upon the loan shark's victims. They had neither the necessary legal tools nor the ability to use them. That situation persists in aggravated form today wherever adequate regulation is lacking.

Legislation encouraging non-commercial lending was effective only to a very limited degree because it attracted but a minute fraction of the amount of capital necessary to supply the demand.

\section{Experimiental Period ${ }^{4}$}

The opening decade of the twentieth century found many states experimenting with laws which covered the entire scale from those imposing the heaviest penalties on violation of the general usury laws to those permitting charges thought to be commercially profitable. The tendency was toward recognition of the necessity for a higher rate of charge, but it was a grudging retreat rather than a clear-cut plan evolved from perception of what was happening. During the experimental period, the various permissive systems devised by the states were all inadequate. Like the earlier prohibitive laws, the new ones covered only limited portions of the possible field. This defect which permitted easy avoidance continued until a broad and simple classification based only on the size of the loans was utilized. Moreover, as the early restraints imposed on lenders were insufficient to prevent fraud and oppression, many of these experimental laws merely entrenched existing evils by legalizing high charges without commensurate controls. Most deficient were the methods used to describe and limit the maximum charges. Discounts, deductions, fees, and special charges were permitted. Such methods of computing charges facilitated the gravest abuses. The extensive trial and error processes of this period demonstrated con. clusively that in the small loan business no system of charging or limiting charges can be enforced unless the lender is confined to an all-inclusive percentage rate applied strictly to the unpaid balances of principal actually received and retained by the borrower."

The most significant development during this period was the research of the Russell Sage Foundation, which commenced in rg07. For the first time a national policy was formulated concerning the small loan business and the methods by which it should be treated legislatively. Public thinking began to crystallize around the findings ${ }^{6}$ of this great philanthropic institution as a nucleus. Definite results ap-

1I. at 27-52, this period is described as $1898-1910$.

Experience from then until now has confirmed this finding. The early obscure methods of stating and limiting maximum charges are still used in Colorado and Nebraska, where they continue to foster deception and abuses and to make strict supervision and enforcement difficult, if not impossible. See Personal Finance Co. of Colorado v. Baker, 105 Colo. I, 94 P. (2d) 460 (1939), in which the court found itself obfuscated by the dizzying consequences of the Colorado rate statement. See also Personal Finance Co. of Council Bluffs v. Gilinsky Fruit Co., 127 Neb. 450, 255 N. W. 558 (1934) (dissenting opinion 256 N. W. 5II), cert. denied, 293 U. S. 627 (1935), in which the Nebraska courr seemed unable to compute the true rate of charge permitted by the Nebraska Act and consequently denied comity in the case of an Iowa contract actually involving a lower charge.

- Wasan, The Salary Loas Business in New Yorx City (Russell Sage Foundation, 1908); Hay. 
peared in statutes which recognized that certain economic changes had taken place which made it necessary for people to borrow small sums of money, that it was essential to permit a commercially profitable rate of charge, but that this privilege should be granted only to those who would submit to a system of regulation designed to enforce rigid adherence to standards of conduct and to prevent fraud and oppression.

\section{Coordinating Period ${ }^{7}$}

The coordinating process, already initiated by the Russell Sage Foundation, was continued with the cooperation of the National Federation of Remedial Loan Associations which had been established in 1909 by the non-commercial lenders operating under earlier acts.

During these years the Foundation and the Federation made frequent public recommendations as to the essentials for adequate small loan legislation. They also prepared and sponsored specific bills before several legislatures. These recommendations were vigorously opposed by most of the commercial lenders then operating. One of the reasons for this opposition no doubt was the fact that the maximum rate of charge recommended was at that time too low for profitable operation.

By 1915 the principles of permission and regulation which later were embodied in the Uniform Small Loan Law had been enacted in primitive but comprehensive form by five large industrial states. ${ }^{8}$ Massachusetts acted in Igri, New Jersey in 1914, New York, Ohio, and Pennsylvania in rgr5 following prior experimental legislation. The stage was thus set for the opening of the modern period.

\section{The Era of the Uniform Small Loan Law}

With this ample experience and with firm convictions concerning the type of legislation required, the institutions leading the attack on loan sharks prepared early in 1916 for campaigns to enact more laws. Unexpected assistance materialized from a few forward-looking commercial lenders who were willing to bring about regulation of their business. Reasonably moderate themselves, they were suffering the consequences of the excesses practiced by others in their business. Self-preservation required that standards of decent conduct be imposed on all. Parenthetically, it may be noted that this development is a typical one; it is being repeated today among the sales finance companies, "industrial" or discount lenders, state and national banks, and others.

The Chattel Lonn Business (Russell Sage Foundation, I909); Ham, A Year's Progress in Remedial Loan Work, Nat. Fed. of Remedial Loan Ass'ns, Proceedings (May 20-21, 1910), 17.

${ }^{7}$ In Gallert, Hilborn and MAY, op. cit. supra note 2, c. IV, 53-88, this period is described as 1910-1916.

Between 1909 and 1915 California, the District of Columbia, Oregon, and Nebraska enacted crude small loan laws differing in material respects from recommendations later made by the Russell Sage Foundation. These acts were not as important in the process of experimenting and coordinating as those of other states. 
Early in Igr6 these progressive commercial lenders organized the American Association of Small Loan Brokers, which was the predecessor of the American Association of Personal Finance Companies, the present trade association of licensed lenders. Their practical knowledge and experience was placed at the disposal of the Foundation. A compromise was reached on a form of regulatory and permissive law. On November 29, 19I6, the Foundation formally recommended the First Draft of Uniform Small Loan Law. ${ }^{9}$ Since rgr 6 the groups mentioned and many other institutions and individuals have constantly endeavored to keep the model act abreast of developments and to obtain its enactment. ${ }^{\mathbf{1 0}}$

Small loan laws have been developed in harmony with social changes under the central guidance of an institution devoted to the public good. In addition to almost 30 states which have enacted such laws, I3 $_{3}$ states have completely revised their legislation once and two states have done so twice since 1925. There have also been scores of amendments to keep state acts up to date. ${ }^{11}$

The process of development of small loan legislation has not been confined to social studies or the legislatures. The courts have played a large part. In the first instance there was a volume of cases involving loan shark activities, which highlighted the necessity for corrective action by the legislatures. Then followed many cases dealing with the validity or construction of small loan laws. As these opinions appeared they often indicated the desirability of changes in the model law. ${ }^{12}$ The extent of judicial activity is shown by the summary table on page II4.

\footnotetext{
'For this accomplishment, from the original studies to enactment of the first twelve or fifteen laws, great credit is due to the vision, intelligence, courage, and energy of Mr. Arthur H. Ham, then Director of the Department of Remedial Loans of the Russell Sage Foundation and now one of its Trustees.

${ }^{10}$ Generalizing very broadly and omitting amendments, the record of enactments and complete revisions of small loan laws inspired by the model act since 1917 has been:

I917-Illinois, Indiana, Maine, New Hampshire, Utah:

1918-Maryland, Virginia;

1919-Arizona, Colorado, Connecticut;

1920-Georgia;

1921-Iowa, Michigan;

I923-Rhode Island;

I925-Florida, Michigan (revision), Tennessee, West Virginia;

1927-Alabama, Missouri, Wisconsin;

1928-Louisiana;

I929-Connecticut, Missouri, and Ohio (all revisions);

1931-Oregon and California (both revisions);

1932-New Jersey and New York (both revisions);

1933-Indiana, West Virginia, and Wisconsin (all revisions);

I 934 -Kentucky;

1935-Colorado and Illinois (both revisions);

I937-Pennsylvania and Rhode Island (both revisions), Arkansas, Hawaii, Vermont;

I939-California and Michigan (both revisions), Minnesota, New Mexico, Dominion of Canada.

The tabulation attempts to show only the years during which the states first gave legislative recognition to the small loan problem or reconstructed a prior small loan law, whether or not the resulting legislation was adequate according to the current or present standards.

${ }^{11}$ See session laws cited in Appendix A, p. 134.

12 For judicial treatment of small loan laws, see Hubachex, Annotattons on Small Loan Laws (Russell Sage Foundation, 1938) hereinafter cited Aswotatjons.
} 
Number of Reported Decisions ${ }^{13}$ Directly Adjudicating Small Loan Laws, by Years

Period

\begin{tabular}{|c|c|}
\hline IgI3 & to $1916 \ldots \ldots \ldots \ldots \ldots$ \\
\hline I9r7 & to $1920 \ldots \ldots \ldots \ldots \ldots$ \\
\hline 1921 & to $1924 \ldots \ldots \ldots \ldots \ldots \ldots$ \\
\hline 1925 & to $1928 \ldots \ldots \ldots \ldots$ \\
\hline 1929 & $\ldots \ldots \ldots \ldots \ldots \ldots \ldots$ \\
\hline I930 & $\ldots \ldots \ldots \ldots$ \\
\hline I93I & $\ldots \ldots \ldots \ldots \ldots \ldots \ldots \ldots$ \\
\hline I932 & $\ldots \ldots \ldots \ldots \ldots \ldots$ \\
\hline
\end{tabular}

Period

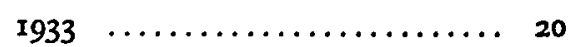

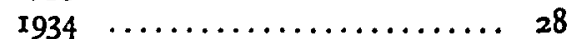

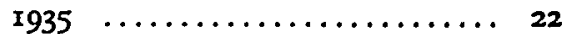

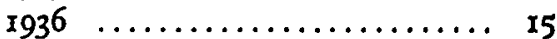

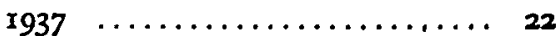

$1938 \ldots \ldots \ldots \ldots \ldots \ldots \ldots \ldots \ldots \ldots$

$1939 \ldots \ldots \ldots \ldots \ldots \ldots \ldots \ldots \ldots \ldots$

r $940-$ To Dec. I ........... r2 $_{2}$

Total Cases ${ }^{14}$

No effort was made to collect and treat small loan decisions separately until 1938, when the author's Annotations on Small Loan Laws ${ }^{15}$ was published. This volume dealt with the 243 small loan decisions ${ }^{16}$ which had been found in the National Reporter System up to January I, 1938. Since this closing date for Annotations on Small Loan Laws, 44 decisions directly involving small loan laws had been reported up to December I, I940, and 7 prior decisions have been found. These 51 decisions, listed by jurisdictions, are cited by states in Appendix B, p. 137. The $294^{17}$ cases dealt with in Annotations on Small Loan Laws and listed in. Appendix B are believed to include all the decisions by American courts of last resort which directly involve small loan laws.

\section{Structure of Uniform SMalt Loan Law ${ }^{18}$}

The philosophy, method, and phraseology of the model acts have been the dominating influences in modern small loan legislation. Because it would be impossible to deal with each state act separately, the Uniform Act will be used as a common denominator for comment applicable to most of the state acts. The successive drafts

${ }^{23}$ The cases decided by federal courts, of course, involved state small loan laws or that of the District of Columbia.

It The research on which this table is based was made from the digest system of the West Publishing Company. This system utilizes the topic heading "Pawnbrokers and Money Lenders" to designate such of the small loan cases as are segregated at all. More than one-third of the decisions wcre located only under widely divergent and comparatively blind headings. The heading "Pawnbrokers and Money Lenders" is peculiarly inappropriate because the Uniform Small Loan Law exempts licensed pawnbrokers and the popular implication of the term "money lender" includes the very things which are outlawed by that act. For the benefit of the profession, the Committce on Law Digests and Bibliography of the Conference on Personal Finance Law has requested the West Publishing Company to adopt a major classification with the heading "Small Loan Acts," under which all cases involving small loan laws will be placed. The orderly and consistent development of small loan and related laws would be facilitated if bench and bar had convenient access to the growing volume of cases on this subject.

${ }^{25}$ Supra note 12.

${ }^{20}$ Ibid., Ivii-lxv, Table of Cases Involving Small Loan Laws, By States.

${ }^{27}$ Due to differences in classification of cases, the total numbers mentioned above and in the preceding table do not cxactly agree.

${ }^{18}$ Annotations, Pt. II, contains a treatment of the cases involving the specific provisions of various state small loan laws, arranged section by section according to the numbering plan of the Uniform Small Loan Law which is also used in this article. As these published citations are exhaustive and easily located, most citations are omitted frọm the résumé of provisions under this heading. 
differ materially from each other, but the section numbering and plan remain basically unchanged which permits fair generalizations as to the essential provisions. The latest published form of Uniform Small Loan Law is set forth in Appendix C, p. $138 .{ }^{19}$

The act operates on an optional system of licensing under which those electing to do so may make higher charges than permitted to others on condition that they submit to strict supervision and regulations. Those not licensed are subjected to new standards of usury in small loans and to new penalties for violations. Numerous special provisions make enforcement easier as a matter of law and more certain as a matter of practice against both licensed and unlicensed lenders.

Sections $I, 18$, and 20 fix the scope of the act.

Section I provides that no unlicensed person shall engage in the business of making loans of $\$ 300$ or less at rates of charge greater than otherwise provided by law. ${ }^{20}$ Section 18 contains substantially the same provision as to single loans. The provisions of the two sections create important new standards of usury in small loans. Loans of credit, goods, and things in action and the loan, use, or sale of credit, when used evasively, are brought into the same class as loans of money for the purpose of determining whether the act applies. ${ }^{21}$ Any discount or consideration exacted for such a loan is treated as interest for the purpose of determining whether

${ }^{20}$ Since the publication of this corrected form of the Sixth Draft minor improvements have been recommended by the Russell Sage Foundation. The Foundation has stated that a seventh draft is now in preparation and will be available early in 1941.

${ }^{20}$ The carly Ohio and Nebraska acts contained no limitation in amount but appeared on superficial reading to contain a system of classification based on the nature of the security taken. These two acts were held constitutional in Wessel v. Timberlake, 95 Ohio St. 2I, II6 N. E. 43 (19I6), and Althaus v. State, 99 Neb. $465,156 \mathrm{~N}$. W. 1038 (1916). These two decisions are contrary to the weight of logic and, by implication, of authority, which is represented by Commonwealth v. Young, 248 Pa. 458, 94 Atl. I4I (1915), rev'g 57 Pa. Super. Ct. 521 (1914). This case held invalid an early Pennsylvania act without limitation in amount of loan. The first two small loan laws enacted after the formulation of the first draft of Uniform Small Loan Law, based on the \$300 classification, were upheld in People $v$. Stokes, 281 Ill. 159, 118 N. E. 87 (1917), and Conmonwealth v. Puder, 261 Pa. 129, 104 Atl. 505 (1918), aff'g 67 Pa. Super. Ct. 11 (1917). These cases were well reasoned and passed favorably upon the system of classification effected by the limitation in the amount of the loan. Thereafter, all subsequent, similar small loan laws have been upheld on the same basis. See Annotations, Pt. I, at 13-26, and cases therein cited.

For a brief discussion of the constitutionality of small loan legislation see GazLert, Hilborn and May, op. cit. supra note $2, \mathrm{c}$. VIII, at $13 \mathrm{I}-1 \mathrm{73}$.

It should be noted that the sinall loan law does not apply to certain credit transactions which are not loans, for example, installment sales financing which if carried on in a certain manner is not the making of loans in the legal sense. Also, it does not apply to banks or transactions of other regulated institutions which are exempted.

${ }^{22}$ The Massachusetts small loan law contains a provision that "The buying . . . of notes . . . shall be considered to be engaging in the business of making small loans." This provision was added by amendment in 1912 to aid in the prosecution of evasions through a then current device. The bona fide purchase of notes in modern sales financing is not a device of evasion. An economic change has taken place. The very recent decision in Modern Finance Co. v. Holz, 29 N. E. (2d) 922 (Mass. 1940) holds, however, that'such-purchase of notes brings a sales finance transaction within the small loan law. Fortunately the court-distinguishes the Massachusetts law from laws using the Uniform Small Loan Law provision, on the ground that the Tatter is-more-general in terms. Under a somewhat parallel situation in Ohio a provision against wage buying (not $\S_{16}$ ) was construed in State v. Mehaffey, $1_{12}$ Ohio. St. 330,147 N. E. 506 (1925), not to apply to bona fide purchases. 
the rate of charge brings the lender within the act. ${ }^{22}$ Generalized provisions with reference to evasions, devices, subterfuges, and pretexts are added to make determinations of usury easier for the courts. Such provisons are little more than repetitions of the general usury principle which requires courts to disregard the form and look to the substance when usury is alleged. It is interesting, however, that courts have mentioned and applied this general language of the act in a manner which gives the impression that they might not have followed the controlling general principle without the statutory provision. ${ }^{23}$

Section 20 exempts banks, trust companies, building and loan associations, credit unions, licensed pawnbrokers, and in some states other entities or institutions which are doing business under special charter or enabling act.

Sections I, I0, I2, I6, I8, I9, and 20 contain the only provisions applicable to non-licensees.

Sections 2 to 9 , inclusive, set up the machinery for the granting and revoking of licenses, payment of application and license fee and costs of examination, filing and maintenance of bond, posting of license, and similar provisions.

Since the publication of the Fifth Draft on January 1,1932 , the granting of licenses has been conditioned upon certain findings of fact by the supervising official having to do with the fitness of the applicant, the welfare of the community, ${ }^{24}$ and the availability of specified minimum capital. Similarly, the supervising official has power to revoke licenses upon finding a violation of the act or regulations or the existence of any fact which would originally have justified denial of an application. ${ }^{25}$

Section to gives the supervising official complete visitorial powers, including access to books and records and the power to take testimony under oath of all persons engaged in the business of making such loans, whether acting or claiming

${ }^{22}$ See London Realty Co. v. Riordan, 207 N. Y. 264,100 N. E. 800 (1913), aff'g 148 App. Div. 854, 133 N. Y. S. 595 (I912); and Stuback v. Sussman, 8 N. Y. S. (2d) 14I ((Sup. Ct. 1938), $a f^{\prime} d$ 256 App. Div. 903 , 10 N. Y. S. (2d) 240 (1939), 281 N. Y. 143, 23 N. E. (2d) 544 (1939); and other cases cited in AnNotations, at I14.

${ }^{23}$ See Jernigan v. Loid Rainwater Co., 196 Ark. 251 , 117 S. W. (2d) 18 (1938).

24 The standard of fitness required is adequatc "financial responsibility, experience, character, and general fitness" "such as to command the canfidence of the community and to warrant belief that the business would be opcrated honestly, fairly, and efficiently within the purposes of the act." The applicant must also show that his conduct of the business will promote "the convenience and advantage of the community." These standards obviously involve flexibility of judgment as to the personal characteristics of an applicant and the general welfare of the community. One or more of these requircments has been sustained against constitutional attack in the following cases involving small loan laws: Financial Aid Corporation v. Wallace, 23 N. E. (2d) 472, 125 A. L. R. 736 (Ind. 1939); Ravitz v. Steurele, $257 \mathrm{Ky}$. 108, 77 S. W. (2d) 360 (1934); Commonwealth v. Puder, 261 Pa. 129, 104 Atl. 505 (1918), aff'g 67 Pa. Super. Ct. II (1917); In re Halck, 215 Cal. 500, 11 P. (2d) 389 (1932); Ex parte Fuller, 102 P. (2d) 321 (Calif. 1940); sce also Equitable Loan Soc. v. Bell, 14 A. (2d) 316 (Pa. 1940).

Similar standards have been construed in cases involving other statutes. The existence of a legitimate demand for small loans is obviously a basic inquiry under the convenience and advantage requirement. The administration of similar requirements, imposed on radio broadcasting stations, on a comparative basis has recently been sustained by the United States Supreme Court. Federal Communications Commission v. Pottsville Broadcasting Company, Fly v. Heitmeyer, and Federal Communications Commission v. Sanders Bros., 309 U. S. 70,146 and 470 ( 1940 ).

${ }_{25}$ The effect of this provision is to give the supervising official powers over the conduct of the licensee as long as he holds his license. See Commonwealth v. Lyons, 15 A. (2d) 851 (Pa. 1940). 
to act as principal or agent or within or without the authority of the act. As to licensees, an annual examination is made mandatory. Along the same lines, Section II requires accounts and records to be kept as required by the official and preserved for purposes of supervision, and requires an annual report under oath to the.supervising official.

Section 12, applicable to licensees, contains specific prohibitions against:

False, misleading, and deceptive advertising ${ }^{26}$ (applies to non-licensees also).

Taking of liens on real estate.

Conducting any other business in a manner which will facilitate evasions of the act. Transacting business under any name or at any place other than those stated in the license. Taking of confessions of judgment or powers of attorney or a written instrument which does not disclose the essential facts or in which blanks are not filled in.

Section 13 contains the one and only grant of a special privilege to licensees. Everything else in the act is in the nature of a requirement or a restriction. Under this section licensees "may lend any sum of money not to exceed $\$ 300$ " and make charges, including interest, at a rate not exceeding a specified percentage per month on unpaid principal balances. ${ }^{27}$ It should be noted that the privilege is limited to loans of money and the maximum rate is expressed as an over-all percentage. The full significance and extreme importance of the latter provision are not always comprehended. ${ }^{28}$

Licensees' charges may not be taken or deducted in advance nor compounded and they must be computed, paid, and expressed as a percentage per month of the unpaid principal balance. There are strict and extensive prohibitions against the contracting for or receiving of any further or other charge or amount whatsoever, on penalty of invalidity of the loan, unenforceability of any claim for principal or charges, and, of course, revocation of license.

Section 14 requires every licensee to:

Deliver to the borrower, when a loan is made, a clear statement of the essential facts of the loan and a copy of Section 13 .

Give the borrower itemized receipts for all payments.

\footnotetext{
${ }^{20}$ See People v. Wahl, Ioo P. (2d) 550 (Calif. 1940), which sustained conviction of a merchant for misleading advertising under a general statute on account of statements which were literally true but were apt to convey an erroneous impression to inexperienced or ignorant persons.

${ }^{27}$ In laws prescribing a maximum rate consisting of two or more different percentages, a provision is necessary to prevent lenders from obtaining a higher rate by splitting up or dividing loans.

${ }^{18}$ Annotatrons, at vii and I74, et seq. The maximum charge which licensees are authorized to make is an aggregate of all charges, whether for interest or otherwise, which may be exacted from the borrower. In effect a new method of computing interest for usury purposes is instituted. Ever the class of bona fide expenses voluntarily authorized by the borrower and incurred for his benefit, which are distinguishable from interest, must be included in the authorized over-all charge. One result of this difference in terminology is to create a situation in which the figure expressing licensed lenders' charges is not comparable with the figure by which the charges of most other lenders are described. A loan by a bank, mortgage company, discount company, or any other such institution may be advertised at $6 \%$ per annum, but when this charge and the additional expenses paid by the borrower are added together, the true rate of cost to the borrower will be higher and may substantially exceed the monthly percentage by which a licensed lender's charge is expressed.
} 
Permit prepayments in any amount at any time.

Cancel, release, and return all obligations and securities signed by the borrower, upon final payments

Display a schedule of charges. ${ }^{29}$

Section $I_{5}$ limits to $\$ 300$ the aggregate indebtedness upon any part or all of which a licensee may collect more than the general contract rate of interest, whether the indebtedness is primary or secondary.

Section 16 provides that the purchase of a wage or salary assignment for a consideration of $\$ 300$ or less, whether or not in good faith, ${ }^{30}$ shall be deemed to be a loan for the purposes of regulation under the act.

Section 17 invalidates wage assignments not taken simultaneously with the making of the loan and requires wage assignments and mortgages on household furniture to be in writing and signed by both spouses unless they have been living apart for at least five months. It makes assignments of future wages given as security for loans collectible only up to $10 \%$ of the borrower's wages and only after a copy of the assignment has been served on the employer.

Section 19 makes violation of specified major provisions a misdemeanor and provides that any loan, in the making or collection of which a misdemeanor shall have been committed, shall be totally void and unenforceable as to principal and all charges.

To the discretionary powers Section 21 was added in the Fifth Draft, authorizing the supervising official to make general rules and regulations and specific rulings, demands, and findings for the proper conduct of the business and the enforcement of the act.

The remaining sections are devoted to mechanical and routine matters, such as repeal of inconsistent acts, separability clause, provision for carry-over of existing licenses under prior acts, and provisions to protect existing legal contracts against impairment.

Not all of the above provisions are essential to the effectiveness of a modern small loan law and the model acts and many state acts contain other provisions not mentioned above which are also important. However, those acts which are effective even though they lack some of the provisions mentioned are made so by unusually vigorous supervision or self-enforcement by licensees. Such de facto results of imperfect laws are in their very nature temporary and should not be used as examples for other legislation,

\footnotetext{
${ }^{20}$ The importance of sections 12 and 14 is that they deprive the licensee of the tools by which loan sharks evade and defeat enforcement of interest limitations. See Anwotstions, at 177. Were it not for these provisions, loan sharks could simply take licenses and proceed much as beforc. Equally important, these provisions are an invitation for responsible people to enter the business.

so $\$ 16$ contains no spccific language to the effect that it is applicable to transactions in good faith but the language must be so construed and the courts have done so in sustaining the constitutionality of the section.
} 


\section{History of Increased Regulation ${ }^{31}$}

From 1917 to 1923 the small loan business licensed under the increasing number of small loan laws in force showed a tremendous growth in volume and developed an efficient operating technique. By 1923 approximately 20 states had small loan laws permitting commercial lending. Most of the original licensees had greatly expanded their invested capital and number of offices. In addition, many new companies, small and large, had been launched. Most of these were formed by the employees of the older companies who had received training in lending methods and accumulated capital for new ventures.

Whereas the original recommended rate of $3 \frac{1}{2} \%$ per month had been thought very low and lending operations at that rate had not produced large profits in the first few years, the improvement in lending technique and the increase in volume of business increased the proportion of gross charges carried to net income. During this period, however, practically all loans by licensees were at the maximum rates permitted by the state acts. Rate competition had not yet become active.

Shortly after the close of the first world war two new significant trends commenced. One was the obtaining of large amounts of capital from the public by companies operating licensed lending offices. The rates of return which had to be offered to obtain this capital were generally high, but not so high that the entrepreneurs could not make profitable use of borrowed funds. The other development was the beginning of large-scale sales of durable goods on credit. This led to the rapid growth of sales finance companies and brought in its train a variety of important economic and social consequences. Because this operation was based on a sale of goods at a credit price, followed by transfer of the paper to a finance company, the transaction was not a loan, according to the controlling legal theory, and usury was not involved. ${ }^{32}$ However, the net result was indebtedness in small amounts owed by members of the same class for whom the small loan problem was acute. The importance of this latter development has not been fully recognized.

As might have been expected, the loan sharks did not submit peacefully to the idea of abandoning their business. They opposed the enactment of the small loan law by every means at their command. Most important, they sought to find every possible loophole in the plan or wording of the law by continuing operations under

${ }^{11}$ See Bradway, Development of Regulation (1938) 196 Awwals 181; Nugent, Changing Philosophy of Small Loan Regulation, id. 205.

${ }^{32}$ See (1935) 2 Law \& Contens. Prob., I 39-287, a symposium devoted to Instalment Selling; and Smith, Rethinking Usury Laws (1938) 196 ANnALs 189.

The following cases hold standard sales finance transactions are not subject to interest restrictions of usury laws: Commercial Credit Co. v. Tarwater, 215 Ala. 123, 110 So. 39, 48 A. L. R. 1437 (1926); General Contract Purchasing Corp. v. Holland, 196 Ark. 675, irg S. W. (2d) 535 (1938); Dunn v. Midland Loan \& Finance Corp., 206 Minn. 550, 289 N. W. 4 I I (I939); or of typical small loan laws: Daniels v. Fenton, 97 Colo. 409, 50 P. (2d) 62 (1935); General Motors Acceptance Corp. v. Swain, I76 So. 636 (La. App. 1937). It should be noted, however, that this form of transaction has been utilized by lenders as a device to evade regulation. See Ryan v. Indiana Finance \& Loan Corp., 91 Ind. App. 622, I71 N. E. 812 (1930), reheuring denied, 172. N. E. 550 (1930); Higgins v. Mosler Acceptance Co., 140 S. W. (2d) 532 (Tex. Civ. App. 1940); Frankfurt Finance Corp. v. Cox, 142 S. W. (2d) 553 (Tex. Civ. App. 1940). 
one or another of the evasive devices. This led to many test cases, some of which were instituted and carried through by the loan sharks themselves. In some instances loopholes were found and in others the loan sharks were unsuccessful.

While all this was happening there was a perceptible change in the attitude of the public toward regulated money lenders. The social stigma which originally attached to the business was slowly diminishing as public understanding of the nature of the business spread and particularly because the behavior of licensed lenders began to deserve public approval.

During this period of testing, expansion, and consolidation of the small loan business the drafts of Uniform Small Loan Law were improved in the light of accumulated experience. The Second Draft, published in August, 1918, merely smoothed out formal and minor imperfections in the First Draft. The Third Draft, published in November, 1919, broadened the wage assignment provision to apply to commissions and other compensation for services, extended the restrictions applicable to liens on household furniture, and continued the process of editorial polishing. The Fourth Draft, published in December, 1923, added three important changes which will serve as illustrations of the manner in which this law was kept abreast of conditions; they related to prepayments, maximum loan, and salary buying.

It had been found difficult to compel certain licensees to accept prepayments from borrowers. This defect in the law was important because several provisions are intended to encourage borrowers to get out of debt quickly. For example, the prescribed method of computing charges rewards quick repayment in contrast to the penalty on prepayments which is imposed by the discount method of charging in advance. The lumping of all charges into one percentage figure is also calculated to encourage prepayments by impressing the borrower with the high rate when compared with general interest rates. Further to accomplish these ends a provision was written into the Fourth Draft compelling licensees to accept prepayments in any . amount at any time.

Troublesome questions also arose in administering a prohibition against any person owing a "licensee, as such, more than $\$ 300$ for principal." The purpose of the provision was to confine licensed lending to small loans. However, literally applied, it would have prevented licensees from acquiring any indebtedness exceeding $\$ 300$ even though legal contract rates of interest or no interest were charged. Accordingly, this provision was so rewritten as to prohibit licensees from charging more than the legal contract rate of interest upon any loan in excess of $\$ 300$. In order to prevent evasions of the prohibition, it was also applied to any indebtedness whether primary, secondary, or contingent.

The most important change in the Fourth Draft was the addition of Section $x 6$. This section required wage purchases for a consideration of $\$ 300$ or less to be 
regulated as though they were loans. ${ }^{33}$ The wage-buying device grew out of the fact that certain large employers followed the practice of delaying wage payments for a substantial period following the date on which they had been earned. Customarily such employers made wage payments one or two weeks late. 'Thus the employee held a chose in action which could be the subject of sale. The practice of wage buyers was to go through the motions of purchasing a portion of the earned wages at a discount, usually $10 \%$, which presumably was compensation for waiting until pay day. As such employees are seldom able to renay the full amount from one pay check, and as the wage buyers refuse to take partial payments, the process is repeated indefinitely. This is simply a disguised small loan business at a rate of $240 \%$ per annum. The pretended purchase of property at a bargain price has long been a favorite device of usurers. By 1923 the business was being done in tremendous volume throughout the southern states and during the next few years it started to spread to the northern industrial area.

These transactions usually could be proved to be loans and hence amenable to the small loan law but such proof required an expenditure of more money than the amount involved in the transaction and certainly more than such wage earners were likely to have at their disposal. Test cases were of no permanent value ${ }^{34}$ as separate proof was required for each transaction "challenged. The only effective means of controlling this practice was to subject all wage purchases, whether bona fide or not, to the small loan law. Section 16 does this. It was first enacted in Maryland in $1924^{35}$ Some 20 small loans laws now contain this section. Wherever it has been enacted the wage buyer has disappeared.

Between 1923 and the publication of the Fifth Draft in January, 1932, far reaching changes took place in the business carried on by licensees and in the entire consumer credit field.

A certain sequence of events had followed the enactment of many small loan laws. First, the loan sharks disappeared. Then the regulated business began to expand. Due to improved lending techniques, increased volume of business, and the availability of public capital, it had become possible to make an attractice net return. A time came when there were too many licensed lenders and too many dollars seeking to be lent. Competition so far had been effective only to a very limited extent in reducing the rates of charge. Instead, it took the form of excessive solicitation and overlending. This in turn led to the borrower's delinquency which fostered collection

\footnotetext{
${ }^{83}$ For a discussion of the salary buying business, as carried on in the absence-of Section 16 , see Gisler and Birkhead, Salary Buying in Kansas City, Missouri (Conference on Personal Finance Law, 1938).

st State v. Mehaffey, 112 Ohio St. 330, 147 N. E. 506 (1925), and see cases cited in Annotatrons, at 106, 157-159.

${ }^{35}$ Laws 1924 , c. 115, p. 236 . The constitutionality of this enactment was attacked and sustained in 1928. Palmore v. Baltimore \& Ohio R. R., 156 Md. 4, 142 Atl. 495 (1928) (with which read Wight v. Baltimore \& Ohio R.R., 146 Md. 66, 125 Atl. 881, 37 A. L. R. 864 (1924)). Subsequently the section has been sustained by the highest courts of a number of jurisdictions. See cases cited in Annotatrons, at 105.
} 
abuses. ${ }^{36}$ These troubles gradually came into bold relief as the industrial states accumulated ten to fifteen years of experience.

By 193I it had become apparent that increased regulation of the licensed lending business was required. This was provided in the Fifth Draft which contained sweeping innovations. The higher interest privilege became more incidental and the general import of the act was changed to a code of business regulation.

Discretionary authority was vested in the supervising official to grant and revoke licenses, and standards were set up which involved not only the fitness of the applicant ${ }^{37}$ but also the convenience and advantage of the community. In order that the number and caliber of the licensees might be subject to readjustment with changes in the community or in the licensees' activities, power was conferred upon the supervising official to revoke licenses if facts or conditions existed which originally would have justified denial of an application for license. The supervising official was given discretionary power to promulgate administrative regulations within the framework of the act and violation of regulations was pade a cause for revocation of license.

In addition, licensees were required to invest a substantial stake in the business. This tended to insure a sense of social responsibility and to confine the business to units of sufficient size to promote efficient operation with resulting low rates of charge. Licensees were also required to segregate the small loan business from other businesses. This tended to prevent evasions and operations of a character outside the remedial intent of the law.

In order to subject the licensed business to intelligent public scrutiny based on facts, an annual report covering all phases of the business was made mandatory and the supervising official was required to publish annually an analysis of such reports.

The Sixth Draft, published in January, 1935, refines and strengthens many details. Its most significant feature was reduction of the recommended maximum rate of charge. This was a further recognition of economic developments within the small loan business. It was also a reflection of the conclusion which had then been reached by the Russell Sage Foundation and others that competition within the small loan business was not fully effective and hence a reduction of the maximum charge by legislative fiat was necessary.

Immediately after the publication of the Fifth Draft in 1932, it was enacted practically in its entirety by New Jersey and New York, both laws being complete revisions of small loan laws which had long been in effect. The following year Indiana, West Virginia, and Wisconsin acted similarly. Since then more than ten additional jurisdictions have followed this path, leaving more than one half the $4^{8}$ states with approved small loan legislation today.

\section{SMall Loan Legislation Now in Force ${ }^{38}$}

To classify the existing laws on this subject is not an easy matter even for casual treatment. A realistic and accurate classification is very difficult. There is no state

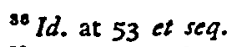

37 See note 24 supra.

${ }^{88}$ There are minor differences between the tabulations of states suggested by Dr. Nugent, Dr. Foster, 
act which follows exactly any one of the six drafts of Uniform Small Loan Law. As has been stated, these drafts are only models intended to be rewritten for each state in conformity with local laws, decisions, public policy, and social conditions. Moreover, the early drafts are no longer acceptable by present standards.

- Among the possible bases for classification are: comprehensiveness, similarity to the Uniform Drafts, and practical effectiveness. The last test requires subdivision in order to acquire real meaning. There are at least three principal respects in which the practical effects of small loan laws must be considered in order to classify them accurately: (I) the providing of capital to be lent under regulation, (2) the regulation in the public interest of the lending business thus created, and (3) the elimination of high-rate, unregulated, commercial lending. Some states have succeeded in the first respect but not in one or both of the last two. Sometimes these deficiencies have been relative only and in some states they have caused miserable failures. No state has succeeded in the third respect without succeeding in the first. These three functional characteristics result largely but not entirely from the organic condition of the small loan law. The situation-legal and practical-in each state determines what the organic structure of the law must be in order to function properly.

The system of classification used in the following tabulation ${ }^{39}$ is based in the first instance on the mere comprehensiveness of the small loan law. With a few exceptions this is also a test of close similarity to the Uniform Small Loan Law. There are 34 states, plus the District of Columbia, Hawaii, and the Dominion of Canada with comprehensive small loan laws; I4 states without. The citations of these 37 small loan laws are set forth in Appendix A, p. $134 .^{40}$

But on the score of effectiveness no such broad statement can be made. Before discussing further the effects of small loan legislation, the writer's classification will be given, as follows:

\section{Group A. [27 States, Hawaii, and Canada]}

The small loan laws of the following jurisdictions are comprehensive in scope, resemble one or more drafts of the Uniform Small Loan Law in important respects, are effective in providing capital to be lent, and, with the exceptions noted, they are reasonably effective both in regulating licensees and in eliminating loan sharks:

and the writer. These variations result largely from the differences between the systems of classification used. In addition, the application of any standard in such a field is to some extent a matter of personal opinion. It is interesting to note the comparative unanimity of opinion in this instance.

See Foster, Le Baron, Small Loan Laws of the United States (Pollak Foundation, 3d ed. 1940) and Younc, Personal Finance Companies and Their Credit Practices (Nat. But. of Econ. Res., 1940) 33-35. See also, Neifeld, Personal Finance Comes of Age (1939) c. V, with much of which the writer cannot agree.

${ }^{89}$ See Younc, op. cit. supra note 38,35, n. 1 , where this system of classification was first stated and applied.

10 The citations in Appendix A include the present code and general statute citations of the 37 comprehensive small loan laws referred to and the session law citations of all small loan laws and amendments enacted in these jurisdietions during and after rgog. These session citations constitute a condensed legislative history of small loan enactments in each jurisdiction. 


$\begin{array}{llll}\text { Arizona* } & \text { Iowa } & \text { Missouri* } & \text { Rhode Island } \\ \text { California** } & \text { Kentucky** } & \text { New Hampshire* } & \text { Utah } \\ \text { Canada* } & \text { Louisiana* } & \text { New Jersey } & \text { Vermont } \\ \text { Connecticut } & \text { Maine* } & \text { New York } & \text { Virginia* } \\ \text { Florida** } & \text { Maryland* } & \text { Ohio** } & \text { West Virginia } \\ \text { Hawaii** } & \text { Massachusetts* } & \text { Oregon*** } & \text { Wisconsin } \\ \text { Illinois } & \text { Michigan } & \text { Pennsylvania } & \\ \text { Indiana } & \text { Minnesota } & & \end{array}$

(*) The laws of the nine jurisdictions marked with a single asterisk lack certain of the more recent improved provisions but are reasonably effective in practice, due either to vigorous supervision and enforcement or to active self-regulation by licensees.

(**) The laws of the six jurisdictions with a double asterisk require special comment:

California. The constitutional background of small loan legislation in California has compelled a unique treatment of the problem in that state. Its law became effective only about one year ago. Whether licensees will be well regulated or loan sharks will be able to find loopholes remains to be seen.

Florida. A special provision exempting purchases of choses in action throws the state open to salary buyers and the act is not statewide in application.

Hawaii. This law is modern in every important respect but almost no licensed small loan business is yet being conducted under it. This is probably due in large part to its isolation from the sources of capital which have developed on the mainland. An industrial loan act under which much loosely controlled small loan business is carried on may partially account for the dearth of small loan law licensees.

Kentucky. A special exemption of loans on the sole security of liens on motor vehicles permits high rate lending of that type.

Ohio. This law is antiquated in several important respects. Licensees are not confined to small loans nor has the supervising official sufficient discretionary power. Hence there are too many licensees and regulation of them is inadequate. Loan sharks, however, have been eliminated.

Oregon. This law authorizes a minimum charge of $\$ \mathrm{r}$, which permits licensees to collect exorbitant rates.

\section{Group B. [3 States]}

The small loan laws of the following states are comprehensive in scope but in several important respects, notably rate structure, they resemble none of the drafts of Uniform Small Loan Law. The acts have provided an adequate amount of capital to be lent but they have not succeeded in regulating licensees. Because of the high and loosely worded maximum rates permitted by these laws there are comparatively few unlicensed loan sharks.
Colorado
Nebraska
New Mexico

\section{Group C. [4 States and the District of Columbia]}

The small loan laws of the following jurisdictions resemble one or more of the drafts of Uniform Small Loan Law in material respects but they are totally ineffective because the maximum rates of charge permitted are too low for profitable commercial operation:
Alabama
Arkansas
District of Columbia Georgia
Tennessee 
Group D. [5 States]

The following states have laws affecting one or more aspects of the small loan business but they are so fragmentary or imperfect that they are totally ineffective:

Delaware Mississippi North Carolina Texas Wyoming

Group E. [9 States]

The following states have no small loan legislation:

Idaho

Nevada Oklahoma

South Dakota

Kansas

North Dakota

South Carolina

Washington

Montana

Summary.

Thirty states, Hawaii, and Canada [Groups A and B] have comprehensive small loan laws which are effective in one or more important respects.

Nine states and the District of Columbia [Groups $C$ and D] have ineffective small loan legislation.

Nine states [Group $\mathrm{E}$ ] have no small loan legislation.

In connection with appraising the effectiveness of small loan laws it is desirable to review, even at the risk of repetition, the manner in which they operate against high rate illegal lending.

\section{How the Uniform Small Loan Law Works as to Loan Sharks}

Morality cannot be achieved by mere legislative fiat, but the Uniform Small Loan Law has undeniably produced business morality in iis own portion of the consumer credit area, to the extent that the loan shark has disappeared wherever it has been enacted. To accomplish this the law works in two ways-legal and practical.

Legally, the loan shark is deterred by new civil and criminal penalties in the act. Before the enactment he might lose his usurious interest, or he might in theory suffer graver civil consequences, according to the different state usury acts. In only a few states was he subject to criminal penalties. For several reasons all these penalties were largely academic. Usury was too hard to prove; there were too many finespun distinctions. Was an amount received by him really interest or was it compensation for something else? Was certain evidence admissible? Could the borrower, as a practical matter, prove his case? The loan shark prevented his victim from obtaining possession of tangible adverse evidence and manufactured favorable written evidence. But the controlling reason why the loan shark did not fear civil or criminal penalties was that few of his victims complained, very few tried to invoke a remedy, and almost none succeeded.

The enactment of an adequate law changed the legal setting by imposing the serious penalties of complete invalidity of borrowers' paper, fine, and imprisonment. In most states it changed the principles of usury in small sums by bringing into the category of interest all "discount or consideration," by applying the rules of interest to other transactions than outright loans of money, and by expressly prohibiting evasive practices. Legal proof of usury became much easier. Most important, it 
created a public officer charged with the duty of enforcing this law; legal weapons were handed to one able to use them.

All these changes would not be effective without the competition of commercial interests. Alabama, Arkansas, and the District of Columbia have had on their books for years small loan laws with most of the legal advantages just mentioned but there is no licensed lending since the laws do not allow commercially profitable rates of charge. These jurisdictions are overrun with loan sharks. Even more persuasive are the experiences of Georgia and Tennessee. These states once had small loan laws with adequate permissive rates and almost no loan sharks; but each state reduced its permitted rate below the profit level, leaving the legal setting otherwise the same, and thereupon licensees ceased to operate and loan sharks flocked in.

It is apparent that the real activating force of the Uniform Law is the legitimate commercial small loan business. It is easy to infer that competition eliminates the loan shark merely by offering borrowers a source of credit at lower rates and under much more pleasing conditions. This is true but it is only a part of the process. A person would be foolish to borrow at $10 \%$ per month when he can do so for $3 \%$, but there are many foolish persons and, if a corrupt source of high cost credit is available, many will use it. This is demonstrated by the recurring operations of outlaw lenders in states having good small loan laws. They creep in, operate for a while, and are put out of business. Economic friction and human frailty permit them to prosper temporarily in the presence of well-operated, low-cost credit agencies. They go out because they are discovered by licensees who set in motion the machinery of the small loan law. The licensees have an investment to protect. They become detective, policeman, and prosecutor. That is an important function of competition in eliminating loan sharks.

Morality has been achieved in this business not by mere passage of a law but by fostering a remedial business which, from enlightened self-interest, polices its own area with everlasting vigilance and vigor.

Economic conditions within a state are sometimes such that there is little pressure to cause wholesale violation of an antiquated small loan law. There are a few states, for example, where salary buying does not flourish notwithstanding the ab. sence of Section 16 because of the type of wage earner and the method of paying wages. Conversely, conditions sometimes arise which bring about serious loan shark activities in states having adequate small loan laws. An example is the case of lower New York City in the period immediately following Prohibition. The existence of organized criminal gangs without a source of income, plus the industrial conditions in that crowded area, led to a loan-shark business in very small sums; the "six for five" racket. Within a few years a vigorous prosecutor broke up this business by the use of the New York Small Loan Law, but while it was operating the act might have been unjustly condemned.

In addition to the ebb and flow of general conditions, the effectiveness of a small loan law is also influenced by the length of time that it has been on the books. 
There is no cycle of time or sequence of events common to all states in this respect; nevertheless loan shark activities must be appraised in each state in view of the age of the small loan law. In a state such as California, where the loan shark evil was rampant before the recent enactment of the small loan law, and particularly because of the complexity of the lending business, the loan shark may disappear rather slowly, fighting as he goes. In Minnesota, which enacted a small loan law at almost the same time, the loan shark disappeared immediately when the law became effective. ${ }^{41}$

As the years go by after the enactment of a small loan law, developments may tend steadily toward improvement of lending conditions or the opposite. Under the older acts the drift is probably away from effectiveness; hence the frequent revisions. In this development much depends upon the wisdom and vigor of the supervising official. In Kentucky the elimination of the loan shark has proceeded slowly but positively since the enactment of its law in 1934. Something remains to be done but progress is in the right direction. In Minnesota, however, one familiar with the processes involved must predict the return of the loan shark if present administrative policies persist. The licensed lending business is so circumscribed and hampered by unwise regulations that commercial profits have been made meager and the sources of credit supply contemplated by the legislation are being starved out. As licensed lending is the moving force which eliminates the loan shark, the intended results cannot be accomplished under this regime. Mere prohibitive legislation was long ago demonstrated to be ineffective in the face of the widespread necessity for small loans.

The type of administration and the type of licensee are sometimes of controlling, although temporary, importance. An outstanding example of success with a very old small loan law is found in Massachusetts, where there has been enlightened and vigorous administration for many years, coupled with an unusually cooperative attitude on the part of the lenders. ${ }^{42}$ At the other extreme are states in which administration has been lax. That condition is apt to be aggravated by recalcitrant licensees. Both extremes may lead to false conclusions by students or lawmaking bodies.

\section{Effects of Other Legislation}

The external fact which is most likely to diminish the social effectiveness of a small loan law is the existence of other statutes having an impact on the consumer credit field. If the public benefits gained by the small loan law movement are not to be lost, means must be found to stop the transferring of loan-shark operations to the protection of statutes which grant obscurely worded privileges without adequate restraints. With these extraordinary rights, there is no necessity for those who other-

\footnotetext{
"For a discussion of loan shark activities in Minnesota prior to enactment of the small loan law in 1939, see Batchelder, The Small Loan Business Unregulated (1939) 205 Anvass 35; and Special Report on Investigation of High Rate Loan Companies in Minneapolis, July I, 1938 to luly 1, r939 (Better Business Bureau of Minneapolis, Inc., 1939).

"2 See Davidson [Mass. Adm'r of Lo2n Agencies], How Regulation Works in Practice (1938) 196 ANNALs 189.
} 
wise would be loan sharks to operate illegally. Their charges are just as extortionate and their practices just as deceptive and oppressive, when they operate within the provisions of such an enabling act, as would be the case if the operation were entirely illegal. In some respects the situation is worse because the loan shark is protected. In Georgia, building and loan acts are being prostituted, in Florida it threatens to be a "limited guaranty company" act, and in several states mortgage loan company laws verge toward shields for loan sharks. Motor vehicle loan laws and "pro rate" laws are other examples.

In many states pawnbroking acts are being utilized in a small way. The most aggravated examples of such perversion of statutes are found under the so-called discount company acts. Of these the Loan and Investment Company Act of Missouri $^{43}$ and the Industrial Loan Company Act of Califronia ${ }^{44}$ are spectacular examples. In 1939, when the Missouri salary buyers were put out of business by the enactment of the appropriate small loan law provisions, they merely shifted plans and are now carrying on large operations, which are just as anti-social as salary buying. They do this under cover of the Missouri Loan and Investment Company Act which permits collection of monthly fees and a $\$ 20$ "hazard fee" for each loan secured by a motor vehicle. ${ }^{45}$ In California the recent enactment of small loan legislation was followed immediately by loan shark activity under the Industrial Loan Company Act which permits exorbitant fees and charges by its deficiencies of regulation and an obscure method of authorizing charges.

The existence of these harbors is beginning to constitute a major public menace. As adequate small loan legislation has expanded throughout the country the loan shark has been crowded into narrower territory. Many imperfect enabling acts of the types mentioned have been on the statute books for years and operations under them have been reasonably sound, due largely to the self-restraint of those who have qualified for the statutory privilege. But now, when the loan shark is driven out at one point he comes in at another, as a discount company, with the benefit of legal protection.

It is obvious that the term "effectiveness of small loan laws" would have little real meaning if the definition of loan shark is to include only illegal lending. The worst salary buying, with no legal sanction whatever, has no more destructive consequences on society than legal money-lending under some of the archaic enabling acts. Often these laws were passed before the necessity for strict restraint was appreciated. It does not seem fair or accurate to classify a small loan law as "ineffective in eliminating loan sharks" when the fault lies with another act which looses on the state a volume of legal but anti-social lending.

\footnotetext{
¿s I REv. Stat. (1929), c. 32, art. 8, $\$ \$ 4979-85$, p. 1375; (Cum. Supp. 1937), c. 32, art. 8, \$\$4982-82a, p. 512. 3 Mo. Stat. Anv. (1932), c. 32, art. 8, $\$ \$ 4979-85$, p. 2280; (Cum. Pocket Pt. 1937), p. 67.

"Gen. Laws (Deering 1937) 1678, Act 3603, \$\$1-12. See also Codes, Laws and Const. AM'ts (Deering, Supp. 1935), art. XX, \$22, p. 2146; Stat. 1935, c. 538, p. 1613.

"since such lenders are not acting in good faith, their plan of operation probably is not protected by the Loan and Investment Companies Act. For provisions of act see note 43 supra.
} 
Absence of Other Legislation

Just as the presence of imperfect enabling acts tends to negative the development of adequate statutory small loan regulation, so the absence of regulatory laws controlling other sources of consumer credit is endangering the same development. These new credit agencies are still dealing on a laissez-faire basis with much the same class of persons for whose protection the small loan laws have been enacted.

The problem involved is not primarily one of business morality. Statutes imposing codes of conduct on businesses which deal with the economically weak are not made necessary by the immorality of the rank and file of a business. To be effective they must be drawn with the realization that a fringe of irresponsible operators will ruin the responsible ones unless all are restrained by a superior force. Competition makes it difficult for one business institution, be it lender, producer, or merchant, to exercise self-restraint without being assured that the others in his business will follow suit. In a business heavily tinged with the public interest, such as one extending credit to consumers, no loopholes can be left, or in due time, whenever pressures are sufficient, the unscrupulous will find and use them. Witness the discount company acts, long used with moderation by decent interests and now prostituted to the great detriment not only of the public but of the respectable discount companies as well.

Small loans made by banks are small loans and they must be considered in developing small loan laws. Likewise, the consumer indebtedness which originates with the sale of a commodity is so nearly identical with the consumer indebtedness which originates with a loan, that realism requires consideration of sales finance transactions in connection with loans. To deal with banks and sales finance companies in a symposium on loan sharks may seem harsh; but let us forget that odious term and consider all consumer credit as one general problem. In that light, all sources of such credit require the attention of anyone concerned with small loan legislation.

Where the small loan business once covered almost the entire economic area characterized by the social problems which we have been discussing, it has now become only a relatively small portion of the field. The phenomenal increase in small loans to consumers by banks is too well known to require elaboration. ${ }^{46}$ Retail instalment credit selling had its original impetus earlier but it also has shown in the last decade a constantly increasing volume. There has resulted not only a staggering aggregate per capita consumer debt but a revolution in the public attitude toward owing money. The far-reaching consequences on the national economy extend into the production aild distribution systems and exert heavy influence on real wages.

As the pressure to sell goods has increased, there has been a growing tendency to use credit as a competitive device. Today the vendor of both hard and soft goods, or the finance company where the paper comes to rest, is apt to look not to the

\footnotetext{
${ }^{\circ} \mathrm{S}$ See Young, Commercial, Banks and Consumer Installment Credit (Nat. Bur. Econ. Res., 1940); and Nugent, Consumer Credit and Economic Stability (Russell Sage Foundation, 1939).
} 
resale value of the merchandise but to the earning capacity of the debtor. This development has made almost identical in social import the consumer debts which originate in purchases and those which originate in loans.

The inquiring mind at once asks two questions: To what degree and in what manner have these changes affected the original small loan problem, the effectiveness of small loan laws which were designed for different conditions, and the operations of licensed lenders? In what directions and to what extent should and can small loan legislation develop in order to adjust the governmental control of these various Jebt sources to keep pace with economic changes?

With reference to the first question: The increase of instalment selling has had a more profound effect on loan problems and on the operations of licensed lenders than has been generally recognized. The remedial effects of the small loan law have been adequate. Necessitous persons have obtained cash on credit at fair rates and under restrictions which have promoted fair dealing. But a new class of borrowers has appeared and the remedial agency set up to care for the necessitous finds itself dealing with all consumers as such. The attitude of the average man toward indebtedness and thrift has been changed. He has been beset on every side by selling pressure calculated to make him want to enjoy today the benefits of tomorrow's earnings and minimizing the weight of the resulting debt burden. Where once he had to obtain money in order to obtain goods, there are now several commercial sources of credit not only willing but anxious to accept his promise to pay. This complete revolution in the consumer's attitude toward borrowing has been too gradual to be detected during any one year, but comparison of today with rg20 makes the extent of the change dramatic.

The enactment of regulatory small loan laws put in motion certain trends which of themselves tended to change the nature of the very business which the laws were designed to deal with. These are too complex and numerous for detailed study but an illustration will suffice. The typical victim of a loan shark paid from 10\% to $20 \%$ per month and borrowed possibly \$25 each from three or four lenders. Averaging these figures, he may have paid $\$ 12$ per month for the use of $\$ 80$. After the enactment of a regulatory law under which charges were $3 \%$ per month, the same man could carry an $\$ 80$ debt for $\$ 2.40$ per month or a $\$ 200$ debt for $\$ 6$ per month. This tremendous reduction in costs did many things. It broadened the market to include many new borrowers. As one reflection of the changing conceptions of debts and thrift, it increased the use of credit by those who were already borrowers. The results of fair dealing and the acceptance of these lending agencies by self-respecting borrowers was also to broaden the market. It should be observed also that other and newer consumer credit agencies have similarly expanded their fields of operation. The resulting overlap becomes rapidly more confusing.

The small loan credit mechanism continues to fulfill its original remedial purpose admirably but it is also doing a new and different business. It takes care of those who are just as insistent upon borrowing money as though they were driven by necessity. 
In this respect licensees now find themselves in the commercial lists as competitors of the new and unregulated. consumer credit agencies just as they have always competed with the illegal agencies and under much the same conditions. That statement is not intended to disparage banks and sales finance companies; it is merely a recognition of facts. But grave social problems are necessarily implied.

It would seem impossible to establish any credit agency through the molding effects of legislation which deals exclusively with the necessitous even if this effort should seem desirable. To do so would require the establishment of legislative standards which are impossible to express and to which, in any event, our people would not submit. Such a development would greatly increase the rates of charge which the necessitous would have to pay in order to obtain their credit. It is wholesome for licensees to lend in volume to those who demand loans but are not strictly necessitous, so long as the demands of the necessitous are well supplied. We cannot too closely segregate or separate the sources of any type of credit. In commercial banking for generations $\$ 1,000$ and $\$ 5,000$ business loans at reasonable rates have been made possible because loans of $\$ 50,000$ and $\$ 100,000$ were being made. Likewise, today, if banks can make consumer loans under proper regulation at lower rates than other agencies, that is a net social gain and should be encouraged, but it cannot be done to the exclusion of commercial lending.

One of the dangers arising from recent developments is the possibility of public misconception of the present dual nature of the licensed small loan business. In the presence of competitive activities of these assorted agencies, the fact may be overlooked that this lender is still taking care of the credit needs of the truly necessitous.

Turning now to the second question: The public interest requires the regulation of all sources of consumer indebtedness. Most of the evils which were created by the operations of loan sharks thirty years ago now exist in varying degrees in the consumer indebtedness created by unregulated agencies. Today there is extensive overlapping of all these agencies. Confusion results. Authorities are unable to follow through the maze. The businesses themselves find legal conflicts and omissions. What was a single problem in I9ro is a triple problem in 1940. The Uniform Small Loan Law closed one gate. Today there are two other openings. It does little good for the body politic to control one source of evil and leave untouched two others.

Banks are exempted from the Uniform Small Loan Law in all but two states. The very nature of banks and their present regulation for other purposes seem to require exemption from this Act. No thoughtful person can honestly oppose the extension of credit in small amounts by banks, provided that it is done under proper controls consistent with the means being used to protect the public in related situations. With the exception of those in New York where a pioneer experimental act has been passed, banks are today the victims of antiquated interest laws just as the decent commercial lenders were before the enactment of adequate small loan laws. It is regrettable that the small loans of most banks today are illegal. Unfortunately,

\footnotetext{
${ }^{47}$ Arizona and Oregon. For provisions of statute, see citations in Appendix A.
} 
one consequence of the illegality is the adoption of many devices and shams. This itself colors the activities and attitudes of banks. In most cases banks have shown commendable moderation, but the result of all these factors is that the small loan departments of a great many banks involve, to a lesser degree, the same anti-social characteristics which have always been found in the operations of loan sharks.

There is the almost universal practice of advertising a figure as a rate of interest when in truth the minimum true interest rate is twice the advertised figure because no credit is given for reductions of principal by instalment repayments. There are the unadvertised fees and fines, the refusal or neglect to give adequate refunds upon prepayment, and the constant use of terms like "service charges" to disguise interest. One can only conclude that there is no fundamental difference between small loans when made by banks and when made by others from the point of view of the need for regulation in the public interest.

It is unnecessary to cite here documentary evidence of the abuses which are being practiced on their debtors by the less responsible sales finance companies. The Massachusetts interim report and the Wisconsin, Indiana, and Michigan laws indicate the public interest in the problem. Many of the evils now found in the sales finance business would readily yield to provisions parallel to those which are already in the small loan laws: For example, the very long repayment schedules and the so-called balloon payment plans under which buyers are entrapped into overlarge indebtedness by small monthly payments, sometimes culminating in a very large final one. To meet similar unwholesome developments in the small loan business the following two provisions have been devised: "No licensee shall make' any contract of loan under which the final payment contracted for matures more than twenty months after the date of the contract" and "Every contract of loan entered into by a licensee shall provide for substantially uniform payments, either of principal or of principal and interest combined, at substantially uniform intervals of time throughout the life of the contract."

In order to regulate sales finance transactions it is not necessary to treat them as loans. Being a part of the consumer credit problem, however, it is essential that they be regulated on a comparable basis. The representations with reference to charges now being made by banks, discount companies, and sales finance companies constitute a veritable babble of tongues. ${ }^{48}$. It is exceedingly important that the various institutions offering credit to the consumer should express their charges in comparable terms. This type of business must always lack some of the elements necessary for effective competition. Whether from necessity or salsman's pressure or mere perversity, the prospective consumer-debtor lacks full bargaining capacity. $\mathrm{He}$ is usually drawn from a class which admittedly requires the protection of the state. The

${ }^{8}$ In recent cease and desist proceedings, the Federal Trade Cominission has ruled that the practice of stating finance charges as $6 \%$ when such percentage is computed on the original unpaid balance as distinguished from the declining balance is unfair competition becausc of its deceptive tendency. The Commission's ruling was judicially sustained in General Motors Acceptance Corp. v. Fed. Trade Comm., 114 F. (2d) 33 (C. C. A. 2d, 1940).

See also Young, op. cit. supra note 38 , at 202-203. 
least that the state can do, in order to promote free competition and to protect him, is to require that the competitive bids for his business be based on the same specifications. For this purpose the clean-cut method of computing and limiting charges which has been one of the essential factors in small loan legislation has proved effective. It is the only means by which costs of credit can be expressed on a comparable basis. To desert it would be a backward step in defiance of the results of forty years of experiment and a surrender to forces already defeated..$^{49}$

The proposed developments are only extensions of similar movements in related fields. A striking example is found in the restraints which have been placed on the merchandising of consumer goods. Forty-two states have enacted statutes to prevent false and deceptive advertising. ${ }^{50}$ Enforcement has resulted in standardization of the representations which may be made concerning goods offered for sale. Honest labeling and standard prices have been brought about by a combination of state regulation and merchants' cooperation. The best merchants, those who do not intend to deceive or oppress, need this protection the most and the wisest ones have been the most vigorous in obtaining it.

The larger and more responsible units in the consumer credit businesses are beginning to realize that it is necessary for self-preservation to impose standards of conduct upon all elements in their business in order to restrain the irresponsible ones. This development is a close and natural parallel to the similar development which took place in the small loan business early in r9I6.

The motivating influence behind all efforts to protect customers is the realization that ultimately private profit must depend upon public service. Due to the characteristics of the customer, this truism is notably applicable to consumer credit businesses. They are extremely sensitive to public opinion. This is in part due to the fact that all such businesses require the special privilege of making an unusually high credit charge in order to operate at all. The public through its law-making bodies is in a position to control the grant of that privilege. The direct relation between continued public service, continued public good-will and continued privilege, accounts to a considerable extent for the progress toward satisfactory regulation which has characterized the development of small loan legislation in the last twenty-five years. Doubtless the same elements will tend to bring about progress in the now unregulated segments of the consumer credit field. It is to be hoped that all these "small credit" agencies will in the future advance in public service and in public esteem and retain the special privileges upon which their continued business life depends.

The weakness of those who require consumer credit is such that fair dealing can be insured only by the imposition of effective restraints on all sources of supply. This can be accomplished by legislation. The present state of affairs requires the

\footnotetext{
4 The writer believes that any method of expressing rates of charge for credit except on an allinclusive percentage basis on unpaid principal balances of the amount actually received and retained by the debtor, fosters evasion, lulls the debtor into belief that his burden is light, tends to prevent getting out of debt, and prevents the consumer from exercising such bargaining powers as he may possess.

${ }^{00}$ See Printer's INK for May 3I, $194^{\circ}$.
} 
preparation and enactment of a consumer credit code which will integrate these various credit mechanisms and regulate them all on a harmonious and coordinated basis. For those who may undertake this task the development of small loan regulation through legislation should contain valuable lessons.

\section{APPENDIX A}

\section{CITATIONS OF SMALL LOAN LAWS}

This table, compiled as of.December $\mathrm{r}, 1940$, contains (in small capitals) the present code or general statute citations and (in ordinary type) the session law citations of the small loan laws of the 37 jurisdictions listed in the text in Groups A, B, and C under the heading Classification of Small Loan Legislation. It also contains a condensed legislative history of small loan enactments in each jurisdiction by reference to the session law citations of all prior small loan laws and amendments enacted during and after 1909.

ALABAMA-General Acts 1927, No. 268, p. 264; new enactment, General Acts Ex. Sess. 1932, No. 339, p. 331. Note: The laws above cited are omitted from the AlA. Code ANN. (1928) and 1936 Supp. thereto. ARIZONA-REv. CODE (Struckmeyer, 1928) c. 45, \$\$1989-2013, p. 481; and Supp. (Courtright, 1936) C. 45,52013, p. 270 .

Laws 1919, c. 91, p. 125, as amended by Laws 1935, c. 39, p. 147. Note: Rev. Code (Struckmeyer, 1928), prepared under authority of Laws 1925, c. 35, revised and reenacted the Small Loan Law.

ARKANSAS—I Digest of Statutes (Pope, 1937) c. 14, \$\$826-855, p. 477.

Acts 1937 , No. 135, p. 467 .

CALIFORNIA-STAT. AND CODE AMDTS. (1939) c. 952, p. 2667; c. 953, p. 2679; c. 1044, p. $2874 ;$ c. 1045, p. 2886. Codes aNd GeN. Laws (Deering, Supp. I939), Act 5825 (1st), 551-23, p. 1356; Act 5825 (2nd), \$5I-24, p: 1366; Act 7700, \$5r-24, p. 1509.

Personal Property Brokers Law: Laws I909, c. 634, p. 969; as amended by: Laws 1911, c. 490, p. 978; Laws I931, c. 273, p. 558; Laws 1933, c. 577; Laws 1939, c. 952, p. 2667, and c. 1044, p. 2874. Small Loan Law: Laws 1939, c. 953, p. 2679, c. 1045, p. 2886. Note: Laws 1939, cc. 952 and 1044 in cffect repealed the prior act and enacted a complete new law. The Small Loan Law was enacted to prevent evasion or avoidance of the basic scheme of regulation provided by the Personal Property Brokers Law. The two laws taken together provide a system of classification and regulation which in practical effect is similar to that of the Uniform Small Loan Law. See also Usury Law, an initiative measure effective 1918, Stat. and Code Ambts. (1919) $\$ \$ 1-5$, p. Ixxxiii; Codes and Gen. Laws (Deering, 1937), Act 3757. \$1-5, p: 1715, and Assembly Constitutional Amendment No. 79, effective 1934.

CANADA-3 Geo. VI, c. 23 (1939).

COLORADO-3 Colo. Stat. ANn. (1935) c. 88, art. 2, \$\$6-21, p. 719, and current Pocket Supp.

Laws 1913, c. 108, p. 400; new enactment Laws 1917, c. 93, p. 350; repealed and new enactment Laws 1919, c. 159, p. 524; new enactment Laws 1935, c. 157, p. 690; as amended by Laws 1939, c. 121, p. $44^{0}$. CONNECTICUT-2 GeN. Stat. Rev. (1930) tit. 37, c. 213, \$\$4066-4082, p. 1314i and Cum. Supp., 1931-1933-1935, tit. 37, c. 213, \$51551c-1556c, p. 675; and 1939 Supp., c. 213, \$51258c-1262c, p. 64x. Public Acts 1919, c. 219, p. 2878; as amended by: Publíc Acts 1923, c. 223, p. 3669; Public Acts 1927, c. 100, p. 4202 , and c. 233 , p. 4302 ; Public Acts 1929, c. 207, p. 4638 ; Public Acts 1933, c. 288; Public Acts 1935, c. 320; Public Acts 1937, c. 172.

DISTRICT OF COLUMBIA-D. C. CODE (1929) tit. 17, c. 2, 5\$21-31, p. 155; 37 STAT. 657 (1913); as amended by 39 Sтит. 1006 (1917). Note: Act of May 29, 1928, and Public Resolution of March 2, 1929, authorized consolidation and codification of the laws. The Small Loan Law was revised and codified by virtue of said acts.

FLORIDA-I Fla. Comp. Gen. Laws ANn. (1927) c. 71, \$\$3999-4017, p. 1431. Id. (Compact ed. 1927) p. 1410.

I Laws 1925, c. 10177, p. 346; as amended by I Laws 1939, c. 19349, p. 718 and c. 19517, p. 1214, and 2 L2ws 1939, c. 20113 , p. 1502. 
GEORGIA-GA. CODE (1933) tit. 25, c. 25-3, \$525-30r-25-319, p. 739. GA. CODE ANN. (1935) Bk. 9, tit. 25, c. 25-3, 5525-301-25-319, p. 352.

Acts 1920, p. 215; 2s amended by Acts 1935, c. 285, p. 394.

ILLINOIS-Rev. Stat. (State Bar ed., 1939) c. 74, \$\$19-46, p. I907. I3 Ann. Stat. (Jores, 1934) (Pocket Supp. 1939) c. 75, 5575.37(I)-75.37(28). Ans. Stat. (Smith-Hurd, 1934) (Pocket Supp. 1939) c. $74,5519-46$.

Laws 1917, p. 553; as amended by: Laws 1925, p. 454; Laws 1933, p. 674 and p. 676; repealed and new enactment, Laws 1935, p. 925.

INDIANA $\rightarrow$ Ann. Stat. (Burns, 1933) tit. I8, c. 30, \$518-300 -18-3005, p. 375. Stat. Ann. (Baldwin, 1934) c. 64 , art. $5,5 \$ 10465-10469$, p. 2196.

Acts 1913, c. 167, p. 457; repealed and new enactment Acts 1917, c. 125, p. 401; as amended by Acts 1933, c. 154, p. 806.

IOWA-CODE (1939) tit. 23, c. 419.1, \$\$9438.01-9438.23, p. 1562.

Laws 1921, c. 35, p. 27; repealed and new enactment Acts Ex. Sess. 1933-1934, c. 125, p. 242.

KENTUCKY-CarroLx's KY. Stat. (Baldwin Rev. I936) c. 32, art. I6, $55883 i-x-883 i-32$, p. 474.

Aets 1934, c. 17, p. 32; $\$ 10($ b) repealed by Acts 1940, c. 191, p. 737 .

LOUISIANA-GEN. STAT. (Dart, I939) tit. 8, c. 14, \$\$768-787, p. 35 I.

Laws 1928, Act. No. 92, p. 93; new enactment, Laws Ex. Sess. 1928, Act No. 7, p. 20; Laws 1940, Act. No. 108, p. 474. Note: Laws 1940, Act No. 108 purports to amend the first Law of 1928 which was declared unconstitutional and thereafter replaced by the second Law of 1928 which was upheld.

MAINE-REv. Stat. (1930) c. $57,5 \$ 143-161$, p. 938.

Public Laws I917, c. 298, p. 428; as amended by: Public Laws 1919, c. 163, p. 164; Public Laws 1923, c. 144, p. 223; Public Laws 1929, c. 195, p. 156, c. 208, p. 168, c. 319, p. 323, and c. 324, p. 330; Public Laws 1939, c. 286, p. 318. Note: Rev. StaT. (1930) prepared under authority of Resolutions of the Legislature of 1927 and 1929, revised and reenacted the Small Loan Law.

MARYLAND-2 ANN. CoDE (Flack, 1939) art. 58A, $\$ 51-20$, p. 2487.

Laws 1912, c. 836 , p. 1621; repealed and new cnactment, Laws 1918, c. 88, p. 197; as amended by: Laws 1924, c. 115, p. 236; Laws 1929, c. 564, p. 1367; Laws 1937, c. 358, p. 713; Laws 1939, c. 560, p. 1133. MASSACHUSETTS-4 ANN. LAws (1933) c. 140, \$596-114, p. 428; and current Pocket Supp.

Acts 1911, c. 727, p. 882; as amended by: Acts 1912, c. 675, p. 740; Acts 1913, c. 347, p. 293; Acts 1916, c. 224, p. 199; Acts 1919, c. 350, pt. 3, art. 7, \$\$45-51, p. 400; Acts 1934, c. 179, \$2, p. 222.

MICHIGAN-CoMp. Laws (1929) (Mason Supp. 1940) tit. 23, c. 240, \$\$12224.1-12224.27, p. 1267. 17 Mrch. Stat. Ans. (1937) (current Pocket Supp.) tit. 23, c. 240, 5523.667 (1)-23.667(27).

Public Acts 1911, No. 105, p. 154; new enactment, Public Acts 1915, No. 228, p. 383; repealed and new enactment, Public Acts 1921, No. 317, p. 585; as amended by Public Acts 1925, No. 181, p. 255; repealed and new enactment Public Acts 1939, No. 21, p. 33.

MINNESOTA-3 Minn. Stat. (Mason, 1927) (Supp. 1940) c. 58, \$57774-4I-7774-67, p. 1295.

Laws 1913 , c. 439, p. 639, amended by Laws 1915 , c. 117 , p. 16I; repealed and new enactment, Laws 1939, c. 12, p. 21 .

MISSOURI-I Rev. StaT. (1929) c. 34, art. 7, 5\$5544-5564, p. 1580, (Supp. I940) p. I85. II Mo. STAT. ANN. (r932) c. 34, art. 7, $\$ 55544-5564$, p. 7704, and current Pocket Supp.

Laws I913, p. 545; repealed by Laws 1933, p. 309; new enactment Laws 1927. p. 252; as amended by: Laws 1929, p. 201; Laws I939, p. 772.

NEBRASKA-CoMp. StaT. (1929) c. 45, art. I, \$\$45-112-45-123, p. I103; (Supp. 1937) c. 45, $\$ 545-124-45-127$, p. 342.

Laws 1913, c. 250, p. 778; repealed and new enacement, Laws 1915, c. 204, p. 435; as amended by: Laws 1929, c. 124, p. 47 ; Laws 1933, c. 159, p. 603.

NEW HAMPSHIRE-2 PUB. LAWs (1926) c. 269, 551-29, p. 1063.

Laws 1917, c. 228, p. 792; as amended by: Laws 1931, c. I63, p. 188; Laws 1933, c. 129, p. 185. Note: Laws r923, c. 4I, authorized revision and codification of the laws. The Small Loan Law, as published in Pob. LAws (1926) was revised and reenacted by virtue of said Act. See also Report of Code Commissioners (1925) c. 269, 55I-29, p. 986.

NEW JERSEY-I REV. STAT. (1937) tit. 17, c. 10, 5517:10-1-17:10-26, p. 71. N. J. STAT. ANN., tit. I7, c. 10, 5517:10-1-17:10.26, p. 261 . 
Laws r910, c. 269, p. 466; as amended by Laws 1912, c. 394, p. 808; repealed and new enactment, Laws 1914, c. 49, p. 75; as amended by: Laws 1928, c. 25I, p. 497; Laws 1929, c. 293, p. 683; repealed and new enactment, Laws 1932, c. 62, p. 94; as amended by Laws 1937, c. 171, p. 413 .

NEW MEXICO-Laws 1939, c. 231, p. 551.

NEW YORK-Consol. Laws (Cahill, Supp. 193I-1935) c. 3, art. 9, \$\$340-365, p. 88; (Supp. 1937) c. 3, art. 9, 5358 , p. 66. 4 Consol. Laws ANN., (McKinney, 1937) art. 9, $\$ 5340-365$, p. 578. Consoz. LAws (Baldwin, 1938) Banking Law, art. 9, $\$ 340-365$, p. 93. Laws of N. Y. (Thompson, 1939) pt. 1 , Banking Law, art. 9, $\$ \$ 340-365$, p. 173 .

2 Lnws I915, c. 588, art. 9, $\$ 340-373$, p. I800; as amended by: 3 Laws 1920, c. 703, p. 1750; Laws 1930, c. 243 , p. 613 , and c. $28 \mathrm{I}$, p. 662 ; repealed and new enactment, Laws 1932, c. 399, p. 869; as amended by Laws I937, c. 425 , p. 1038 .

OHIO-THROckmorton's CODE ANN. (Baldwin Rev., 1940) pt. II, tit. 2, c. 25, $\$ \$ 6346 \cdot 1-6346 \cdot 13$, p. 438. Gen. Code Ann. (Page, I937-39) pt. II, tit. 2, c. 25a, $\$ \$ 6346-1-6346-13$, and current Pocket Supp. Laws igr1, p. 469; repealed and new enactment, Laws 1915, p. 281; as amended by: Laws 1917, 513, p. 506, at p. 509; Laws 1923, p. 209; Laws 1929, p. 43 and p. 479; Laws 1933, p. 435; Laws 1935, p. 45; Laws 1937, p. 78; Laws 1939, S.295, 51 .

OREGON-OREGON CODE (1930) (Supp. 1935) tit. 22, c. 27, \$522-2701-22-2728, p. 487.

General Laws 1913, c. 278, p. 527; repealed and new enactment, General Laws 1915, c. 219, p. 286; repealed and new enactment, Laws 1931, c. 385, p. 8ro; as amended by: Laws 1933, c. 426, p. 726; Laws r935, c. 20 r, p. 297.

PENNSYLVANIA-STAт. ANN. (Purdon, 1930) (r939led.) tit. 7, c. 27, 5575I-760, p. 55. Id. (Compact ed. 1936), tit. 7, c. $27, \$ \$ 751-760$, p. 87.

Laws I909, No. 290, p. 5r8; repealed and new enactment, Laws r913, No. 285, p. 429; new enactment, Laws 1915, No. 432, p. I012; as amended by: Laws 1919, No. 186, p. 375; Laws 1937, No. 268, p. 989. RHODE ISLAND-GeNeraI LAwS (1938) c. 149, p. 345.

Publia Laws 1923, c. 2312, p. 24; as revised by Public Laws 1923-1924, c. 427, p. 24; as amended by: Public Laws 1927, c. 1060, p. 284; Public Laws 1937, c. 2496, p. 27. Note: Public Laws 1937, c. 2496, in effect repealed the prior act and enacted a complete new law.

TENINESSEE-CODE (1932) pt. I, tit. 14, c. 33, \$\$6721-6743, p. 1510. CODE (Michic, 1938) pt. I, tit. 14, c. $33, \$ \$ 6721-6743$, p. IOI5. CODE ANN. (Williams, 1934), tit. 14, c. 33, \$\$6721-6743, p. 600; and current Pocket Supp.

Public Acts 1917, c. 62, p. 133; new enactment, 2 Public Acts 1925, c. 153, p. 5; as amended by Public Atts 1937, c. 34, p. 130. Note: CODE or 1932, authorized by the Legislature and prepared by Code Commission, modified and reenacted the Act of 1925 . It also incorporated into Small Loan Law 53 of Public Acts of 1925 , c. 76, p. 168, which Act sought to amend Act of r9r7.

TERRITORY, OF HAWAII-LaWs I937, c. 232A, p. 241.

UTAH-REv. Stat. (1933) tit. 7, c. 8, $\$ \$ x-9$, p. 199.

Public Laws I9I7, c. 4I, p. 1I6; as amended by Public Laws 1939, c. 19, p. 31. Note: Rev. StAT. (1933) authorized by virue of Public Laws 1927, c. i6, Public Laws 1929, c. 37, and Public Laws 1931, c. 61, revised and reenacted the Small Loan Law of 1917.

VERMONT-Acts 1937, No. 184, p. 206; as amended by Acts 1939, No. 198, p. 236.

VIRGINIA-CODE ANN. (1936) tit. 37, c. 166C, $554168(38)-4168(57)$, p. 1262; (Cum. Supp. 1940) tit. 37, c. $166 \mathrm{C}, \$ 4168(57)$, p. $34 \mathrm{I}$.

Acts 1918, c. 402 , p. 662; as amended by Acts 1920, c. 299, p. 414; as amended and reenacted by Acts 1922, c. 300 , p. 502; as amended by: Acts 1928, c. 152, p. 563; Laws 1940, p. 298.

WEST VIRGINIA-CODE ANN. (1937) c. 47, art. 7A, $\$ 94653(1)-4653(26)$, p. 1633 .

Acts 1925, c. 91, P. 37r; as amended by Acts 1929, c. 24, p. 146; repealed and new enactment, Acts I933, c. I3, p. 45.

WISCONSIN-WIs. STAT. (I939) c. 214, \$5214.01-214.28, p. 2270.

Laws r927, c. 540, \$\$214.01-214.22, p. 942; repealed and new enactment, Laws 1933, c. 347, p. 724 . Note: Laws r933, c. 347 , as published was reenacted by Laws r933, c. 443. 


\title{
APPENDIX B
}

\section{TABLE OF CASES INVOLVING SMALL LOAN LAWS, BY STATES}

\author{
Supplementary to the writer's Annotations on Small Loan Laws \\ (Russell Sage Foundation, I938)
}

This table lists all decisions directly involving small loan laws which have been reported in the National Reporter System between January 1, 1938, the closing date for Annotations on Small Loan Laws, and December $x$, 1940. It also lists seven decisions which were reported prior to January I, I938, but were not cited in Annotations. This table, together with the table appearing at pages lvii to lxv of Annotations is thought to be an exhaustive collection of such decisions.

UNITED STATES-In re Brown, 24 F. Supp. 166 (D. C. N. D. Ala. 1938). Noteman v. Welch, 108 F. (2d) 206 (C. C. A. Ist, 1939) aff' 26 F. Supp. 437 (D. C. Mass. 1939).

ALABAMA-In re Brown, (for citation see above heading UNITED STATES).

ARKANSAS-Jernigan v. Loid Rainwater Co., 196 Ark. 25I, II7 S. W. (2d) I8 (1938).

CALIFORNIA-Ex parte Fuller, 102 P. (2d) 321 (1940). (See also cases cited under heading "Special California Issues," Annozations, 40-41).

COLORADO-Siebers v. Labor Finance Corp., roo Colo. 40, 64 P. (2d) 1263 (1937). Siebers v. Disque, 102 Colo. 39, 76 P. (2d) I108 (1938). Personal Finance Co. of Colorado v. Baker, I05 Colo. 1, 94 P. (2d) 460 (1939).

CONNECTICUT-Equitable Industrial Loan Soc. v. Kelly, 124 Conn. 346, 199 Atl. 766, I16 A. L. R. 1357 (1938).

FLORIDA-Beasley v. Coleman, 136 Fla. 393 , 180 So. 625 (1938).

GEORGIA-Springer v. City Inv. Co., 57 Ga. App. 655, x96 S. E. 110 (1938). Kent v. Citizens Mut. Inv. Ass'n, 186 Ga. 91, 196 S. E. 770 (1938). Denson v. Peoples Bank, 186 Ga. 619, 198 S. E. 666 (1938). Denson v. Peoples Bank, 58 Ga. App. 518, 199 S. E. 324 (1938). Hartsfield Co. v. Fulwiler, 59 Ga. App. 194, 200 S. E. 309 (1938). Citizens Mut. Ins. Ass'n v. Glass, 59 Ga. App. 359, I S. E. (2d) 50 (1939). Atlanta Finance Co. v. Brown, 187 Ga. 729, 2 S. E. (2d) 415 (r939). Craddock v. Woods, 60 Ga. App. 377, 3 S. E. (2d) 924 (1939). Zink v. Davis Finance Co., 6r Ga. App. 39, 5 S. E. (2d) 588 (1939). Zachry v. Alexander, 60 G2. App. 897, 5 S. E. (2d) 599 (1939). Wicks v. Community Loan \&c Inv. Corp., 189 G. 620, 7 S. E. (2d) 385 (1940).

ILLINOIS-Kraus Bond \& Mig. Organization, Inc. v. Vicari, 300 Ill. App. I92, 20 N. E. (2d) 865 (1939). INDIANA-Porter v. Stolkin, Iox Ind. App. 705, 200 N. E. 74 (1936). Financial Aid Corporation v. Wallace, 23 N. E. (2d) 472, 125 A. L. R. 736 (1939).

IOWA-Miller v. Schuster, 227 Iowa 1005, $289 \cdot$ N. W. 702 (1940).

KENTUCKY-Commonwealth ex rel. Grauman v. Continental Co., $275 \mathrm{Ky} .238$, 121 S. W. (2d) 49 (1938).

LOUSIANA-Industrial Loan Co. of Monroe v. Noe, 183 So. $x 75$ (La. App. 1938).

MASSACHUSETTS-Burnes v. New Mineral Fert. Co., 218 Mass. 300 , 105 N. E. ro74 (1914). Bennett v. 'Tremont Securities Co., 221 Mass. 218, I08 N. E. 891 (1915). Raulines v. Levi, 232 Mass. 42, I2I N. E. 500 (1919). Chamberlain v. Employers' Liability Assurance Corp., 289 Mass. 4r2, 194 N. E. 3ro (1935). Noteman v. Welch, (for citation see above heading UNITED STATES). Modern Finance Co. v. Holz, 29 N. E. (2d) 922 (1940).

MISSOURI-Vaughan v. Graham, 12I S. W. (2d) 222 (Mo. App. 1938).

NEW HAMPSHIRE-Auto Owners' Finance Co. v. Coleman, 89 N. H. 356, 199 Atl. 365 (1938).

NEW JERSEY-Dunn v. Mayor and Council of City of Hoboken, 85 N. J. L. 79, 88 Atl. 1053 (Sup. Ct. 1913). Bassano v. Rutherford Nat. Bank, 126 N. J. Eq. 141, 8 A. (2d) 189 (1939). Howard v. Confidential Loan Plan, I25 N. J. L. 74, I3 A. (2d) 492 (Sup. Ct. 1940).

NEW YORK-Stuback v. Sussman, 8 N. Y. S. (2d) -14I, $a f f^{\prime} d$ Io N. Y. S. (2d) $240,28 \mathrm{I}$ N. Y. 143, 23 N. E. (2d) 544 (1939). Personal Finance Co. of New York v. Gross, 170 Misc. 166, 9 N. Y. S. (2d) 801 (Mun. Ct. 1939). Application of Ritter, 172 Misc. 120, 14 N. Y. S. (2d) 676 (Sup. Ct. 1939). 
Brooklyn Loan Corporation v. Gross, City Marshal, 259 App. Div. I65, I8 N. Y. S. (2d) 179 (1940). Domestic Finance Corp. v. Williams, 20 N. Y. S. (2d) 467 (Co. Ct. 1940). MeGoldrick v. Family Finance Corp., 22 N. Y. S. (2d) 186 (Sup. Ct. 1940).

OfIIO-Dichl v. Interstate Loan Co., 57 Ohio App. 532, 15 N. E. (2d) 170 (1937). Capital Loan \& Savings Co. v. Biery, 134 Ohio St. 333, I6 N. E. (2d) 450 (1938). Columbus Postal Employees Credit Union, Inc. v. Mitchell, 62 Ohio App. 343, 23 N. E. (2d) 989 (1939). Columbus Postal Employees Credit Union, Inc. v. Mitchell, 63 Ohio App. 281, 26 N. E. (2d) 593 (I940).

PENNSYILVANIA-In re People's Investment Co., 56 Pa. Super. Ct. 90 (Igr4):

TENNESSEE-Knowling v. State, 138 S. W. (2d) 416 (Sup. Ct. 1940). B. A. C. Corporation v. Darr, 138 S. W. (2d) 420 (Sup. Ct. 1940). Whaley v. State, 139 S. W. (2d) 255 (Sup. Ct. 1940).

WASHINGTON-Mirgon v. Sherk, 196 Wash. 69o, 84 P. (2d) 362 (1938).

\title{
APPENDIX C
}

\section{SIXTH DR.AFT}

\section{GENERAL FORM OF UNIFORM SMALL LOAN LAW}

\author{
With Corrections to June 1, 1938, Including Explanatory Notes. \\ As Published by Russell Sage Foundation, New York.
}

TTTLE-A Bill for an Act to define and regulate the business of making loans in the amount of three hundred dollars $(\$ 300)$ or less; to permit the licensing of persons engaged in such business; to authorize such licensees to make charges at a greater rate than unlicensed lenders; to prescribe maximum rates of charge which licensees are permitted to make; to regulate assignments of wages or salaries, earned or to be earned, when given as security for any such loan or as consideration for 2 payment of three hundred dollars $(\$ 300)$ or less; to provide for the administration of this Act and for the issuance of rules and regulations therefor; to authorize the making of examinations and investigations and the publication of reports thereof; to provide for a review of decisions and findings of the (Note 2) under this Act (Note 3); to prescribe penalties; and to repeal (Note 4) and to repeal all acts and parts of acts whether general, special, or local, which relate to the same subject matter as this Act, so far 2s they are inconsistent with the provisions of this Act (Note 5).

LICENSE-Section I. No person shall engage in the business of making loans of money, credit, goods, or things in action in the amount or of the value of three hundred dollars $(\$ 300)$ or less and charge, contract for, or receive on any such loan a greater rate of interest, discount, or consideration therefor than the lender 'would be permitted by law to charge if he were not a licensee hereunder (Note I) except as authorized by this Act and withour first obtaining a license from the (Note 2) hereinafter called the Commissioner (Note 6). The word "person," when used in this Act, shall include individuals, co-partnerships, associations, and corporations unless the context requires a different meaning.

APPLICATION AND FEE-Section 2. Application for such license shall be in writing, under oath, and in the form prescribed by the Commissioner, and shall contain the name and the address (both of the residence and place of business) of the applicant, and if the applicant is a co-partnership or association, of every member thereof, and if a corporation, of each officer and director thercof; also the county and municipality with street and number, if any, where the business is to be conducted and such further information as the Commissioner may require. Such applicant at the time of making such applieation shall pay to the Commissioner the sum of fifty dollars (\$50) as a fee for investigating the application and the additional sum of one hundred dollars (\$100) as an annual license fee (Note 7 ) for a period terminating on the last day of the current calendar year; provided, that if the application is filed after June thirtieth in any year such additional sum shall be only fifty dollars (\$50) (Note $7 \mathrm{~d}$ ). In addition to the said annual license fee every licensee hereunder shall pay to the Commissioner the actual costs of each examination as provided for in Section Io of this Act.

Every application shall also prove, in form satisfactory to the Commissioner, that he or it has avail. able for the operation of such business at the location specified in the application, liquid assets of at least twenty-five thousand dollars $(\$ 25,000)$.

BOND-Section 3. The applicant shall also at the same time file with the Commissioner a bond to be approved by him in which the applicant shall be the obligor, in the sum of ope thousand dollare $(\$ \mathrm{r}, 000)$ with one or more sureties to be approved by him whose liability as such sureties need not 
exceed the said sum in the aggregate. The said bond shall run to the State for the use of the State and of any person or persons who may have cause of action against the obligor of said bond under the provisions of this Act. Such bond shall be conditioned that said obligor will faithfully conform to and abide by the provisions of this Act and of all rules and regulations lawfully made by the Commissioner hereunder, and will pay to the State and to any such person or persons any and all moneys'that may become due or owing to the State or to such person or persons from said obligor under and by virtue of the provisions of this Act.

REQUIREMENTS FOR LICENSE-Section 4. Upon the filing of such application and the payment of such fees and the approval of such bond, the Commissioner shall investigate the facts and if he shall find (a) that the financial responsibility, experience, character, and general fitness of the applicant, and of the members thereof if the applicant be a co-partnership or association, and of the officers and directors thereof if the applicant be a corporation, are such as to command the confidence of the community and to warrant belief that the business will be operated honestly, fairly, and efficiently within the purposes of this Act, and (b) that allowing such applicant to engage in business will promote the convenience and advantage of the community in which the business of the applicant is to be conducted, and (c) that the applicant has available for the operation of such business at the specified location liquid assets of at least twenty-five thousand dollars $(\$ 25,000)$ (the foregoing facts being conditions precedent to the issuance of a license under this Act), he shall thereupon issue and deliver a license to the applicant to make loans in accordance with the provisions of this Act at the location specified in the said application, which license shall remain in full force and effect until it is surrendered by the licensee or revoked or suspended as hereinafter provided; if the Commissioner shall not so find he shall not issue such license and he shall notify the applicant of the denial and return to the applicant the bond and the sum paid by the applicant as a license fee, retaining the fifty dollars $(\$ 50)$ investigation fee to cover the costs of investigating the application. The Commissioner shall approve or deny every application for license hereunder within sixty (60) days from the filing thereof with the said fees and the said approved bond.

DENIAL OF APPLICATION AND RIGHT OF REVIEW-If the application is denied, the Commissioner shall within twenty (20) days thereafter file with the Department of (Note 8) a written decision and findings with respect thereto containing the evidence and the reasons supporting the denial, and forthwith serve upon the applicant a copy thereof, which decision and findings may be reviewed by a writ of certiorari or writ of mandamus within thirty (30) days after the filing thercof (Note 9).

POSTING OF LICENSE-Section 5. Such license shall state the address at which the business is to be conducted and shall state fully the name of the licensec, and if the licensee is a co-partnership or association, the names of the members thereof, and if a corporation, the date and place of its incorporation. Such license shall be kept conspicuously posted in the place of business of the licensee and shall not be transferable or assignable.

ADDITIONAL BOND.-Section 6. If the Commissioner shail find at any time that the bond is insecure or exhausted or otherwise doubtful, an additional bond to be approved by him, with one or more sureties to be approved by him and of the character specified in Section 3 of this Act, in the sum of not more than one thousand dollars $(\$ 1,000)$, shall be filed by the licensee within ten (Io) days after written demand upon the licensee by the Commissioner.

MINIMUM ASSETS-Every licensee shall maintain at all times assets of at least twenty-five thousand dollars $(\$ 25,000)$ either in liquid form available for the operation of or actually used in the conduct of such business at the location specified in the license.

PLACE OF BUSINESS, ETC.-Section 7. Not more than one place of business shall be maintained under the same license, but the Commissioner may issue more than one license to the same licensee upon compliance with all the provisions of this Act governing an original issuance of a license, for each such new license.

REMOVAL-Whenever a licensee shall wish to change his place of business to a street address other than that designated in his license he shall give written notice thereof to the Commissioner who shall investigate the facts and, if he shall find that allowing such licensee to engage in business in such new location will promote the convenience and advantage of the community in which the licensee desires to conduct his business, he shall attach to the license in writing his approval of the change and the date thereof which shall be authority for the operation of such business under such license at such new location; if the Commissioner shall not so find he shall deny the licensee permission so to change the location of his place of business, in the manner specified and subject to the provisions contained in the last paragraph of Section 4 of this Act. No change in the place of business of a licensee to a location outside of the original (Note ro) shall be permitted under the same license. 
PAYMENT OF LICENSE FEE-Section 8. Every licensee shall, on or before the twenticth day of each December, pay to the Commissioner the sum of one hundred dollars (\$100) as an annual license fee for the next succeeding calendar year and shall at the same time file with the Commissioner a bond in the same amount and of the same character as required by Section 3 of this Act.

REVOCATION OF LICENSE-Section 9. The Commissioner shall, upon ten (xo) days' notice to the licensee stating the contemplated action and in general the grounds therefor, and upon reasonable opportunity to be heard, revoke any license issucd hercunder if he shall find that:

(a) The licensee has failed to pay the annual license fee or to maintain in effect the bond or bonds required under the provisions of this Act or to comply with any demand, ruling, or requirement of the Commissioner lawfully made pursuant to and within the authority of this Act; or that

(b) The licensee has violated any provision of this Act or any rule or regulation lawfully made by the Commissioner under and within the authority of this Act; or that

(c) Any fact or condition exists which, if it had existed at the time of the original application for such license, clearly would have warranted the Commissioncr in refusing originally to issue such license.

SUSPENSION OF LICENSE-The Commissioner may upon three (3) days' notice and a hearing, suspend any license for a period not exceeding thirty (30) days, pending investigation.

The Commissioner may revoke or suspend only the particular license with respect to which grounds for revocation or suspension may occur or exist, or, if he shall find that such grounds for revocation or suspension are of general application to all officers, or to more than one office, operated by such licensee, he shall revoke or suspend all of the licenses issued to said licensee or such licenses as such grounds apply to, as the case may be.

SURRENDER OF LICENSE-Any licensee may surrender any license by delivering to the Commissioner written notice that he thereby surrenders such license, but such surrender shall not affect such licensee's civil or criminal liability for acts committed prior to such surrender.

No revocation or suspension or surrender of any license shall impair or affect the obligation of any pre-existing lawful contract between the licensee and any borrower.

REINSTATEMENT OF LICENSE-Every license issued hereunder shall remain in foree and cffect until the same shall have been surrendered, revoked, or suspended in accordance with the provisions of this Act, but the Commissioner shall have authority on his own initiative to reinstate suspended liecnses or to issue new licenses to a licensee whose lieense or licenses shall have been revoled if no fact or condition then exists which clearly would have warranted the Commissioner in refusing originally to issue such license under this Act.

FILING REASONS FOR REVOCATION, ETC.-Whenever the Commissioner shall revole or suspend a license issued pursuant to this Act, he shall forthwith file with the Department of (Note 8 ) a written order to that effect and findings with respect thereto containing the evidence and the reasons supporting the revocation or suspension, and forthwith serve upon the licensee a copy thereof, which order may be reviewed by a writ of certiorari or writ of mandamus within thirty (30) days after the filing thereof (Note 9).

EXAMINATIONS-Section Io. For the purpose of discovering violations of this Act or securing information lawfully required by him hereunder, the Commissioner may at any time, either personally or by a person or persons duly designated by him, investigate the loans and business and examine the books, accounts, records, and files used therein, of every licensee and of every person who shall be engaged in the business described in Section I of this Act, whether such person shall act or claim to act as principal or agent, or under or without the authority of this Act. For that purpose the Cómmissioncr and his duly designated representatives shall have free access to the offices and places of business, books, accounts, papers, records, files, safes, and vaults of all such persons. The Commissioner and all persons duly designated by him shall have authority to require the attendance of (Note 11) and to examine under oath all persons whomsoever whose testimony he may require relative to such loans or such business or to the subject matter of any examination, investigation, or hearing.

ANNUAL EXAMINATION-The Commissioner shall make such an examination of the affairs, business, office, and records of each licensec at least once each year (Note $7 \mathrm{c}$ ). The actual cost of every examination shall be paid to the Commissioner by every licensee so examined, and the Commissioner may maintain an action for the recovery of such costs in any court of competent jurisdiction.

BOOKS AND RECORDS-Section $\mathrm{r}$. The licensee shall keep and use in his business such books, accounts, and records as will enable the Commissioner to determine whether such license is complying with the provisions of this Act and with the rules and regulations lawfully made by the Commissioner hereunder. Every licensee shall preserve such books, accounts, and records, including cards used in the card system, if any, for at least two (2) years after making the final entry on any loan recorded therein. 
ANNUAL REPORTS-Each licensee shail annually on or before the fifteenth day of March file a report with the Commissioner giving such relevant information as the Commissioner reasonably may require concerning the business and operations during the preceding ealendar year of each licensed place of business conducted by such licensee within the State. Such report shall be made under oath and shall be in the form preseribed by the Commissioner, who shall make and publish annually an analysis and recapitulation of such reports.

ADVERTISING-Section 12. No licensee or other person shall advertise, print, display, publish, distribute, or broadenst or cause or permit to be advertised, printed, displayed, published, distributed, or broadeast, in any manner whatsoever any statement or representation with regard to the rates, terms, or conditions for the lending of money, credit, goods, or things in action in the amount or of the value of three hundred dollars $(\$ 300)$ or less at a greater rate of charge than lenders not licensed hereunder would be permitted by law to make, which is false, misleading, or deceptive (Note 12). The Commissioner may order any licensee to desist from any conduct which he shall find to be a violation of the foregoing provisions.

The Commissioner may require that rates of charge, if stated by a licensee, be stated fully and clearly in such manner as he may deem necessary to prevent misunderstanding thereof by prospective borrowers.

LIENS ON REAL ESTATE-No licensee shall take a lien upon real estate as security for any loan made under this Act, except such lien as is created by law upon the recording of a judgment (Note I3). $^{3}$.

OTHER BUSINESS IN SAME OFFICE-No licensee shall conduct the business of making loans under this Act within any office, room, or place of business in which any other business is solicited or engaged in, or in association or conjunction therewith, except as may be authorized in writing by the Commissioner upon his finding that the character of such other business is such that the granting of such authority would not facilitate evasions of this Act or of the rules and regulations lawfully made hereunder.

No licensee shall transact such business or make any loan provided for by this Act under any other name or at any other place of business than that named in the license.

NO CONFESSIONS OF JUDGMENT, ETC.-No licensee shall take any confession of judgment or any power of attorney. No licensee shall take any note, promise to pay, or security that does not accurately disclose the actual amount of the loan, the time for which it is made, and the agreed rate of charge, nor any instrument in which blanks are left to be filled in after execution.

MAXIMUUM RATE OF CHARGE-Section 13. Every licensee hereunder may lend any sum of money not to exceed three hundred dollars $(\$ 300)$ in amount and may contract for and receive thereon charges 2t a rate not exceeding three and one-half per centum $\left(3 \frac{1 / 2}{2}\right)$ per month on that part of the unpaid principal balance of any loan not in excess of one hundred dollars (\$100) and two and one-half per centum $\left(2 \frac{1}{2} \%\right)$ per month on any remainder of such unpaid principal balance (Note 14 ).

SPLIT LOANS PROHIBITED-No licensee shall induce or permit any borrower to split up or divide any loan. No licensee shall induce or permit any person, nor any husband and wife jointly or severally, to become obligated, directly or contingently or both, under more than one contract of loan at the same time, for the purpose or with the result of obtaining a higher rate of charge than would otherwise be permitted by this section (Note 14a).

No charges on loans made under this Act shall be paid, deducted, or received in advance, or compounded. All charges on loans made under this Act (a) shall be computed and paid only as a percentage per month of the unpaid principal balance or portions thereof, and (b) shall be so expressed in every obligation signed by the borrower, and (c) shall be computed on the basis of the number of days actually elapsed, for the purpose of which computations a month shall be any period of thirty (30) consecutive days. In addition to the charges herein provided for no further or other amount whatsoever shall be directly or indirectly charged, contracted for, or received.

If any amount other than or in excess of the charges permitted by this Act is charged, contracted for, or received, the contract of loan shall be void and the licensee shall have no right to collect or receive any principal, charges, or recompense whatsoever.

REQUIREMENTS FOR MAKING AND PAYMENT OF LOANS-Section 14. Every licensee shall:

Deliver to the borrower at the time any loan is made a statement (upon which there shall be printed a copy of Section 13 of this Act) in the English language showing in clear and distinct terms the amount and date of the loan and of its maturity, the nature of the security, if any, for the loan, the name and address of the borrower and of the licensee, and the agreed rate of charge;

Give to the borrower a plain and complete receipt for all payments made on account of any such loan at the time such payments are made, specifying the amount applied to charges and the amount, if any, applied to principal, and stating the unpaid principal balance, if any, of such loan; 
Permit payment to be made in advance in any amount on any contract of loan at any time, but the licensee may apply such payment first to all charges in full at the agreed rate up to the date of such payment;

Upon repayment of the loan in full, mark indelibly every obligation and security signed by the borrower with the word "Paid" or "Cancelled," and release any mortgage, restore any pledge, cancel and return any note, and cancel and return any assignment given to the licensee by the borrower;

Display prominently in each licensed place of business a full and accurate schedule, to be approved by the Commissioner, of the charges to be made and the method of computing the same.

PROHIBITION-Section, 15. No lieensee shall directly or indirectly charge, contract for, or receive any interest, discount, or consideration greater than the lender would be permitted by law to charge if he were not a licensee hereunder (Note I) upon the loan, use, or forbcarance of money, goods, or things in action, or upon the loan, use, or sale of credit, of the amount or value of more than three hundred dollars $(\$ 300)$. The foregoing prohibition shall also apply to any licensee who permits any person, as borrower or as endorser, guarantor, or surety for any borrower, or otherwise, to owe directly or contingently or both to the licensee at any time a sum of more than three hundred dollars $(\$ 300)$ for principal (Note 14b).

WAGE ASSIGNMENTS-Section 16. The payment of three hundred dollars $(\$ 300)$ or less in money, credit, goods, or things in action as consideration fot any sale or assignment of, or order for, the payment of wages, salary, commissions, or other compensation for services, whether carned or to be earned, shall for the purposes of regulation under this Act be deemed a loan secured by such assignment, and the amount by which such assigned compensation exceeds the amount of such consideration actually paid shall for the purposes of regulation under this Act be deemed interest or charges upon such loan from the date of such payment to the date such compensation is payable. Such transaction shall be governed by and subject to the provisions of this Act.

VALIDITY AND PAYMENT OF ASSIGNMENTS-Section 17. No assignment of or order for payment of any salary, wages, commissions, or other compensation for services, earned or to be carned, given to secure any loan made by any licensee under this Act, shall be valid unless the amount of such loan is paid to the borrower simultancously with its execution; nor shall any such assignment or order, or any chattel mortgage or other lien on houschold furniture then in the possession and use of the borrower, be valid unless it is in writing, signed in person by the borrower, nor if the borrower is married unless it is signed in person by both husband and wife, provided that written assent of a spouse shall not be required when husband and wife have been living separate and apart for a period of at leas: five months prior to the making of such assignment, order, mortgage, or lien.

AMOUNT COLLECTIBLE UNDER ASSIGNMENT-Under any such assignment or order for the payment of future salary, wages, commissions, or other compensation for services, given as security for a loan made by any licensee under this Act, a sum not to exceed ten per centum (10\%) of the borrower's salary, wages, commissions, or other compensation for services shall be collectible from the $\mathrm{cm}$ ployer of the borrower by the licensee at the time of each payment to the borrower of such salary, wages, commissions, or other compensation for services, from the time that a copy of such assignment, verified by the oath of the licensee or his agent, together with a similarly verified statement of the amount unpaid upon such loan, and printed copy of Section 17 of this Act is served upon the employer.

PROHIBITION-Section 18. No person, except as authorized by this Act, shall directly or indirectly charge, contract for, or receive any interest, discount, or consideration greater than the lender would be permitted by law to charge if he were not a licensee hereunder (Note $I$ ) upon the loan, use, or forbearance of money, goods, or things in action, or upon the loan, use, or sale of credit of the amount or value of three hundred dollars $(\$ 300)$ or less.

The foregoing prohibition shall apply to any person, who by any device, subterfuge, or pretense whatsoever shall charge, contract for, or receive greater interest, consideration, or charges than is authorized by this Act for any such loan, use, or forbearance of money, goods, or things in action or for any such loan, use, or sale of credit.

No loan of the amount or value of three hundred dollars $(\$ 300)$ or less for which a greater rate of interest, consideration, or charges than is permitted by this Act has been charged, contracted. for, or received, wherever made, shall be enforced in this State and cvery person in anywise participating thercin in this State shall be subject to the provisions of this Act, provided that the foregoing shall not apply to loans legally made in any State which then has in effect a regulatory small loan law similar in principle to this Act.

PENALTIES-Section 19. Any person and the several members, officers, directors, agents, and employees thereof, who shall violate or participate in the violation of any of the provisions of Sections $I$, 12, 13, 14, or 18 of this Act, shall be guilty of a misdemcanor (Note 15).

Any contract of loan not invalid for any other reason, in the making or collection of which any act 
shall have been done which constitutes a misdemeanor under this Section, shall be void and the lender shall have no right to collect or receive any principal, interest, or charges whatsoever.

EXCEPTED LENDERS-Section 20. This Act shall not apply to any person doing business unider and as permitted by any law of this State or of the United States relating to banks, savings banks, trust companies, building and loan associations, credit unions, or licensed pawnbrokers.

REGULATIONS-Section 21. (Note 16 ) is hereby authorized and empowered to make general rules and regulations and specific rulings, demands, and findings for the enforcement of this Act, in addition hereto and not inconsistent herewith.

PRE-EXISTING CONTRACTS-Section 22. This Act or any part thereof may be modified, amended, or repealed so as to effect a cancellation or alteration of any license or right of a licensee hereunder, provided that such cancellation or alteration shall not impair or affect the obligation of any pre-existing lawful contract between any licensee and any borrower.

STATUS OF PRE-EXISTING LICENSES-Section 23. Any person having a license under (Note 17), in force when this Act becomes effective, shall notwithstanding the repeal of the said (Note 17), be deemed to have a license under this Act for a period expiring six (6) months after the said effective date, if not sooner revoked, provided that such person shall have paid or shall pay to the Commissioner as a license fee for such six (6) months' period the sum of fifty dollars (\$50) (Note $7 \mathrm{~b}$ ) and shall keep on file with the Commissioner during such six (6) months' period the bond required either by this Act or by the said (Note I7). Any such license so continued in effect under the provisions of this Act shall be subject to revocation during such six (6) month' period as provided in Section 9 of this Act except that it may not be revoked during such six (6) months' period either upon the ground that such licensee bas not the minimum amount of assets required in Section 6 of this Act or upon the ground that the convenience and advantage of such community will not be promoted by the operation therein of such business.

Section $24 \ldots$ (Note 18$) \ldots$

REPEAL-Section 25. . . (Note 4) ... and all Acts and parts of Acts whether general, special, or local, which relate to the same subject matter as this Act, so far as they are inconsistent with the provisions of this Act, are hereby repealed.

STATUS OF PRE-EXISTING OBLIGATIONS-Nothing herein contained shall be so construed as to impair or affect the obligation of any contract of loan between any licensee under the said (Note 17) and any borrower, which was lawfully entered into prior to the effective date of this Act.

DECISIONS AFFECT ADJUDICATED SECTIONS ONLY-Section 26. If any clause, sentence, section, provision, or part of this Act shall be adjudged to be unconstitutional or invalid for any reason by any court of competent jurisdiction, such judgment shall not impair, affect, or invalidate the remainder of this Act, which shall remain in full force and effect thereafter.

Section 27. This Act shall take effect immediately (Note 19).

\section{NOTES}

Note x. If there is only one interest statute of general application, then, the maximum percentage rate fixed by such statute may be inserted in place of the words "the lender would be permitted by law to charge if he were not a licensee hereunder." The recommended language is preferable, however.

The same situation exists in Sections 1,15 , and 18 .

Note 2. Here insert title of licensing official.

Note 3. If a separate department or supervising official is created, there should be added to the title of the bill descriptive language covering the creation of such department or office, the duties thereof, the raising and disbursing of revenues, and other special provisions incident to such creation. It is recommended that a subdivision of the Banking Department be created in charge of a special deputy to supervise the small loan business and administer this Act, such subdivision to be designated as the Bureau of Personal Finance. See Note 16, Section 21.

Note 4. Here insert titles of Acts to be specifically repealed in whole or in part.

Note 5. Here insert enacting clause.

Note 6. The title "Commissioner" is used throughout this form of Act for convenience, but local usage should fix this title and it should then be substituted for "Commissioner" throughout the Act. "The licensing official" may be used in lieu of a specific title.

Note 7. It is thought that \$10o per year per office will return enough revenue to cover the cost of necessary general supervision including the preparation, analysis, and tabulation of the annual report.

If the fiscal policy of the State or other considerations make it advisable to collect the full costs of individual examinations from each office in a stated annual fee, $\$ 200$ or $\$ 250$ should provide sufficient funds for this purpose. In such an event 
(a) the greater amount should be substituted in Section 2,

(b) one-half thereof should be inserted in Section 23,

(c) at (Note 7) should be inserted "and in full payment of all expenses for examinations under and for administration of this Act,"

(d) the sentence following (Note $7 \mathrm{~d}$ ) should be eliminated, and

(c) the sentence following (Note 7e) should be eliminated.

See also Note 16, Section 21, regarding disposition of revenues under this Act.

Note 8. Here insert the name of the department charged with the duty of administering the Act. If a subdivision of a larger department administers the Act, the principal department should be named here.

Note $\dot{9}$. The provisions for judicial review of the determinations, rulings, findings, and similar discretionary acts of the licensing official will necessarily vary widely with the codes of judicial procedure of the several states and the constitutional and statutory provisions relating thereto. If satisfactory general provisions exist and apply to this situation, the specific provisions hereof may be eliminated. In states which have a sufficiently flexible judicial code, a direct action to review the Commissioner's acts is the best procedure. See also similar material in Sections 9 and 24 and Note 18.

Note ro. Here insert a description of the municipality according to the system of nomenclature employed within the State, for example, "municipality," or "city," "town," or "village." The political subdivisions used should be those which best reflect an integral urban unit or community.

Note Ir. Special treatment will be required in order effectually to authorize the Commissioner to require the attendance of witnesses. In some states such power cannot be so delegated. See Note 15.

Note 12. The following words may be added at this point if deemed desirable: "or, in the case of a licensee, which refers to the supervision of such business by the State of . . . or any department or official thereof."

Note 13. This paragraph is not intended to prevent licensees from taking and recording valid judgments and must be so drawn as to prevent such a result. The exception must therefore be drafted in such language as the local law requires in order to accomplish this result.

Note 14. The maximum rate of charge of $3^{1 / 2}$ per cent a month on that part of any loan balance not exceeding $\$ 100$ and $2 \frac{1}{2}$ per cent a month on that part exceeding $\$ 100$ is recommended as an initial rate in all states. This combination of rates permits a maximum charge ranging from $3^{1 / 2}$ per cent 2 month on outstanding balances of $\$ 100$ or less to 2.83 per.cent a month on outstanding balances of \$300. The rate is designed to attract aggressive competition by licensed lenders following the enactment of the law in order to drive unlicensed lenders out of business. This rate should be reconsidered after a reasonable period of experience with it.

From the experience with various maximum rates in many states, it is clear that it is no longes possible to make generalizations with reference to an adequate maximum rate for all states. The distribution of population, the character and stability of the industries in urban areas, costs of lending revealed by reports of licensees, local legislation and tradition affecting the forms of security available to licensees, the extent of unlicensed lending, the size of loans in which it occurs, and many other factors should be considered in revising the maximum rate in any state.

In some states, it would undoubtedly be possiblo to reduce the initial maximum rate secommended here. In others, a lower rate would probably be impracticable, and a careful study of the question might produce evidence in favor of an increase in the initial rate. The evidence available at present leads us to believe that $2^{1 / 2}$ per cent a month, applying to all contracts, is the lowest maximum rate which would be effective under the most favorable conditions, and that this rate is too low to be effective in most states.

A reduction of the maximum rate in New Hampshire to 2 per cent a month led to the destruction of the licensed small loan business in that State, and a similar reduction in West Virginia tended to eliminate licensed lending on chattel mortgages and wage assignments and encouraged a rapid rise of illegal lending at exorbitant interest rates. In New Jersey, where costs of lending appear to be as low as, if not lower than, those in any other state, a rate of $2 \frac{1}{2}$ per cent 2 month on all loans appears to be an adequate maximum. But in Missouri a similar maximum is clearly inadequate and unlicensed high-rate lending in sums of less than $\$ 100$ is prevalent. It seems probable that reductions below the initial maximum recommended here would be found to be generally possible in the northern industrial states, while reductions below the initial rate would probably prove to be generally undesirable in southern and western states where urban areas are distant from each other and the existing demand is for relatively small loans.

The relationship between the possibility of lower maximum interest rates and the vigilant and aggiessive exercise by the supervising officer of the discretionary powers granted by the Fifth and Sixth Drafts should be clearly recognized. Without the discretionary powers granted by the Fifth and Sixth Drafts 
of the Uniform Law and without forceful administration of the Act, it would probably be unwise to attempt reduction below the 3 and $3 \frac{1 / 2}{2}$ per cent a month maximum rates now in effect in most states.

The general recommendation of a graduated rate is a departure from the previous policy of the Department of Consumer Credit Studies. Heretofore the Department has consistently recommended a flat maximum rate applying to all contracts. This change has been adopted only after an examination of all of the available expense data for the small loan business and after an examination of the experience with graduated rates in several states. The possibility of lower rates of charge on larger loans has always been recognized. But the tlat rate was the most easily enforced by state supervising officers, and most readily understood by the borrower. It was anticipated that competition would reduce the going rate for the most profitable loans and that this competition would be most effective if the maximum charge were expressed as a single rate.

The graduated rate has been recommended in spite of these advantages of the flat rate rather than because they no longer exist. Three circumstancs have influenced the choice. First, the greater profitableness of larger loans has led to a vigorous competition for such loans to the neglect, although not to the exclusion, of loans of smaller sums. Because of this neglect of the smaller loans by licensed lenders, unlicensed lenders have frequently been able to build up a business in very small loans at exorbitant rates. We believe the graduated rate will tend to encourage the making of smaller loans by licensed lenders, and to prevent unlicensed lending in these sums. Second, although competition has succeeded in reducing rates of charge on larger loans in many communities, the maximum rate has continued to prevail in others. There is a tendency for excessive competition to increase costs of lending, and consequently to restrain competitive rate reductions. Third, the expense burden in dollars upon borrowers of large sums is high. While it is not considered socially desirable that very small loans should bear their full share of operating costs, it has seemed proper to provide a less inequitable distribution of these costs than was possible under 2 flat maximum rate.

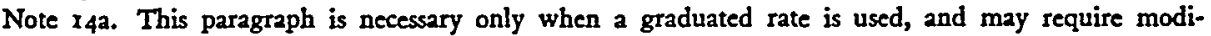
fication to meet local conditions in some states.

Note $14 \mathrm{~b}$. This section should be modified for use in certain states in which licensees under the existing small loan act are engaged in the business of financing the liquidation of accounts receivable of retail merchants and professional men. In these instances it is recommended that this practice be permitted in the discretion and with the specific approval of the supervising officer.

Note 15. Local considerations may require changes in or elaboration of the nature of the crime and/or its.penalties. It may also be necessary to add a paragraph attaching 2 criminal penalty for failure of the licensee (or others) to submit to subpoena, produce documents, make reports, etc. See Note II.

Note 16. Here insert full title of the licensing official. In this section insert the appropriate paragraphs if it is desired to create 2 new department or subdivision or official, providing for revenues and disbursements, defining new duties, etc. See Note 3. All general rules and regulations and all denials, revocations, and suspensions of licenses should be required to have the written approval of the head of the principal department if a subdepartment administers this Act.

In this section should also appear provisions for the disposition of license fees, investigation fees, and any other revenue, if the fiscal policy or statutory requirements of the State make such special provisions necessary or desirable; if so, the title of the Act should contain the words "providing for the disposition of revenues received hereunder." It is recommended that all revenues go direct to the supervising department for the expenses of administering the Act, if such is possible.

Note 17. Here cite any existing regulatory small loan law similar in principle to this Act.

Note 18. This section should prescribe the procedure for judicial review of all discretionary acts of the Commissioner which mighe be open to the construction that they are exercises of judicial powers, including all findings, decisions, and determinations and the application of all rules and regulations by demands or requirements made upon licensees. In Sections 4 and 9 gencral provisions are made for the right of review in the specific cases covered by such sections. In Section 24 corresponding provisions should be made to cover all other cases. In addition, if required in any State, the specific procedure for all cases shotld be provided for in appropriate detail. The last paragraphs of Sections 4 and 9 may have to be redrafted to bring them into accord with Section 24 as to procedure. Where the judicial code does not specifically so provide, provision should be made that review is by the state court of general, original jurisdiction.

This section should also prescribe such necessary procedural details as may be required under the judicial decisions and by the statutes and constitution of the particular state in connection with the exercising of discretionary powers; for example, the manner of giving notices, the length of notice, the making and recording of findings, the nature of hearings, and other compliances with the requirements of due process.

Note 19. If a greater number of affirmative votes is required to pass an act effective immediately, this section should be changed or eliminated, depending on local requirements. 